\title{
COMMENT
}

\section{LAW FOR SALE: A STUDY OF THE DELAWARE CORPORATION LAW OF 1967}

\begin{abstract}
"Meanwhile the little community of truck-farmers and clamdiggers have had their cupidity excited by the spectacle of their northern neighbor, New Jersey, becoming rich and bloated through the granting of franchises to trusts which are to do business everywhere except in New Jersey, and which are to go forth panoplied by the sovereign state of New Jersey to afflict and curse other American communities. . . . In other words little Delaware, gangrened with envy at the spectacle of the truck-patchers, sand-duners, clam-diggers and mosquito wafters of New Jersey getting all the money in the country into her coffers, - is determined to get her little tiny, sweet, round, baby hand into the grab-bag of sweet things before it is too late." 1
\end{abstract}

"WHEREAS, the State of Delaware has a long and beneficial history as the domicile of nationally known corporations; and WHEREAS, the favorable climate which the State of Delaware has traditionally provided for corporations has been a leading source of revenue for the State; and

WHEREAS, many States have enacted new corporation laws in recent years in an effort to compete with Delaware for corporate business; and

WHEREAS, there has been no comprehensive revision of the Delaware Corporation Law since its enactment in 1898 [sic]; and

WHEREAS, the General Assembly of the State of Delaware declares it to be the public policy of the State to maintain a favorable business climate and to encourage corporations to make Delaware their domicile . . . ."2

The sovereign state of Delaware is in the business of selling its corporation law. This is profitable business, for corporation law is a good commodity to sell. The market is large, and relatively few producers compete on a national scale. The consumers of this commodity are corporations, and as we shall see, Delaware, like any other

1 Little Delaware Makes a Bid for the Organization of Trusts, 33 AMr. L. REv. 418, 419 (1899).

2 Law of December 31, 1963, v. 54, ch. 218 [1963] Del. Laws 724. 
good businessman, tries to give the consumer what he wants. In fact, those who will buy the product are not only consulted about their preferences, but are also allowed to design the product and run the factory.

Delaware from time to time redesigns and improves its product to keep ahead of the competition. In 1963, Delaware felt compelled to do just that. The second passage quoted above is the preamble to a statute appropriating $\$ 25,000$ to study and recommend revisions to Delaware's corporation law. This Comment will describe the process used to redesign the law, and discuss some of the features of the finished product. Finally, the Comment will evaluate the consequences of the revision for the "non-consumer" public.

\section{History of the Product}

In the early nineteenth century, the process by which a corporation was formed began to shift from incorporation by special act of legislature to incorporation under general laws; New York passed the first such law in $1811 .^{3}$ Incorporation under a general law rather than by special act was at first optional, but constitutional modification gradually made it mandatory. Delaware, in its Constitution of 1897, became the thirty-fifth state to adopt such a requirement. ${ }^{4}$ Most statutes of that period contain restrictions on corporate organization; the Delaware statute of 1871 , for example, applied only to companies drying, canning, manufacturing and preparing fruits and other products of Delaware, and limited its capital to a minimum of $\$ 10,000$ and a maximum of $\$ 100,000 .^{5}$

In 1898, a special session of the Delaware legislature was called to draft a new corporation law. A bill providing, inter alia, that fifty per cent of a corporation's capital stock had to be paid in before the corporation could start business and that shareholders would be liable for assessment for up to double the par value of their stock was considered and defeated. ${ }^{6}$ After this, in the interval between the special session of 1898 and the regular session of 1899, "the present competitive incorporation policy of Delaware was formulated." ?

A group consisting of a financial editor of a New York newspaper, a New York lawyer, and two Dover (Delaware) lawyers formed an unofficial committee to draw up a "liberal" bill ${ }^{8}$ and pilot it through the legislature. The Dover lawyers planned to organize a company to do the work entailed in incorporating and to provide corporations with resident agents for service of process; the New York members thought

3 R. Larcom, The Delaware Corporation 1 (1937).

4 See DeL. Const. art. IX, § 1 ; R. LARCoM, supra note 3 , at 3.

5 Law of March 21, 1871, v. 14, ch. 152 [1874] Del. Laws 380 (repealed 1875).

6 See R. LARCOM, supra note 3 , at 8.

7 Id. 9.

$8 \mathrm{~A}$ "liberal" corporation law is one containing a maximum number of enabling provisions and fettering the corporation with a minimum number of responsibilities to, for example, its creditors, its shareholders, and the public. 
they could get business for the new company because of their Wall Street contacts. ${ }^{9}$ Their new company would have to have a good product to sell; since New Jersey was then the most successful of the states actively competing in the incorporating business, the framers of the Delaware law patterned their statute after New Jersey's. By adopting much of the wording of the New Jersey statute, they could insure some certainty in judicial construction, ${ }^{10}$ a valuable selling point. ${ }^{11}$ Since it is also good business to undersell your competitors, "[a] nother important device by which the draftsmen of the Delaware law hoped to attract the incorporating business was low corporate taxes." 12 Comparative figures indicate that Delaware's taxes were set a bit lower than New Jersey's in all respects. ${ }^{13}$

"The revenue possibilities of the new law became the dominant consideration," 14 and the draftsmen were successful in convincing the legislature of the merits of a liberal bill. Whatever conservatives were left over from 1898 apparently changed their minds, for this bill was passed in 1899 without a dissenting vote in the House. ${ }^{15}$ After 1915, with the passage in New Jersey of Governor Woodrow Wilson's more restrictive "Seven Sisters Acts," 16 the number of corporations chartered in Delaware began to grow considerably. ${ }^{17}$ During thirty of the thirtyfour years from 1899 to 1933, corporation revenues comprised at least twenty per cent of Delaware's total revenues; for twenty-three of the thirty-four years, they comprised twenty-five per cent or more. ${ }^{18}$ Delaware was doing well.

\section{Drafting and Passing the 1967 Statute}

The three groups responsible for the 1899 law are still active in shaping Delaware's corporation law. They are the corporation service companies, which have grown considerably since their inception in $1899 ;^{19}$ the legislature, which seems to have become more docile; ${ }^{20}$ and the Delaware bar, which consists of approximately 500 lawyers, about 425 of whom practice in Wilmington. ${ }^{21}$ Approximately twenty-

${ }^{9}$ See R. LARCoM, supra note 3, citing J. Wolcott, The Development of the Delaware Corporation, unpublished thesis submitted to Harvard Graduate School of Business Administration (no date).

10 See R. Larcom, supra note 3, at 25-26.

11 See note 45 infra and accompanying text.

$12 \mathrm{R}$. LARCOM, supra note 3 , at 17 .

13 See id. 17-20.

14 Id. 9-10.

$15 I d .9$.

${ }^{16}$ Law of February 19, 1913, ch. 18, [1913] N.J. Laws 32 (repealed 1917).

17 See R. LARCOM, supra note 3, at 155.

18 See id. 168-69.

19 See text accompanying note 9 supra.

20 See text accompanying notes 71-75 infra.

21 See 1 Martindale-Hubbell Law Directory 689-99 (1969). 
five of these Wilmington lawyers comprise the full-time corporate bar. ${ }^{22}$ It is a very friendly bar, considered by outsiders to be quite competent in dealing with the Delaware corporation law, ${ }^{23}$ and headed by three firms-Morris, Nichols, Arsht \& Tunnell, Richards, Layton \& Finger, and Potter, Anderson \& Corroon. ${ }^{24}$

The 1963 statute calling for a revision of Delaware's corporation law empowered the Secretary of State, Elisha Dukes, to spend the appropriated money "for consultants and assistance in such manner as will, in his discretion, most expeditiously accomplish" the revision. ${ }^{25}$ He decided to form the Delaware Corporation Law Revision Commission, made up of himself and nine others.

The Chairman was Clarence A. Southerland, former Chief Justice of the Delaware Supreme Court and of counsel to Potter, Anderson \& Corroon; he was only moderately active because of poor health. ${ }^{26}$ The Vice Chairman was Richard F. Corroon, a partner in the same firm and one of the Commission's three most active members. He was first admitted to the New York Bar in 1939, not becoming a member of the Delaware Bar until 1946, and he still maintains membership in the Association of the Bar of the City of New York. ${ }^{27}$ Martindale-Hubbell lists some of his firm's clients: Penn Central Railroad, Corporation Trust Co. (a corporation service company), Prudential Life Insurance Company, Metropolitan Life Insurance Company, and the Insurance Company of North America. ${ }^{28}$

The other two most active members were S. Samuel Arsht, a partner in Morris, Nichols, Arsht \& Tunnell, and Henry M. Canby, a partner in Richards, Layton \& Finger. Arsht was First Vice President of the Delaware Bar Association from 1961 to 1963 and maintains membership in the American Law Institute and the American Judicature Society. His firm's clients include Allis-Chalmers, Christiana Securities, Coca-Cola, E.I. duPont de Nemours \& Co., Ford Motor Co., International Latex Corp., Kaiser Aluminum \& Chemical Corp., Texaco, United Air Lines, United States Steel, Warner Bros.-Seven Arts Ltd. ${ }^{29}$ Canby was Arsht's successor as

22 Interview with Irving Morris, Esq., in Wilmington, Delaware, July 25, 1968 [hereinafter cited as Morris Interview].

23 This is the judgment of Willard P. Scott, Esq., Chairman of the American Bar Association Committee on Corporate Laws. Interview, in New York City, July 22, 1968 [hereinafter cited as Scott Interview].

24 Id.

25 Law of December 31, 1963, v. 54, ch. 218, [1963] Del. Laws 725.

26 Interview with Professor Ernest L. Folk, III, in Charlottesville, Virginia, July 2, 1968 [hereinafter cited as Folk Interview]. The names of the Commission members were furnished by Professor Folk.

27 See 1 Martindale-Hubbelt Law Directory $1779 B$ (1969).

$28 \mathrm{Id} .1780 \mathrm{~B}$.

29 Id. $1777 \mathrm{~B}-78 \mathrm{~B}$. 
President of the Delaware Bar Association, and his firm's clients include General Motors, Aetna Group, Getty Oil and Shell Oil. ${ }^{30}$

A somewhat less active member was Irving Morris, a partner in the Wilmington firm of Cohen \& Morris. Morris was a Deputy Attorney General of Delaware in 1955 and was Vice President of the Delaware Bar Association from 1954 to $1958 .^{31} \mathrm{He}$ was on the Commission in his capacity as a plaintiff's lawyer, since he handles a large percentage of the derivative suits brought in Delaware. The corporation service companies were also represented by Alfred Jervis, manager of the Delaware Office of the Corporation Trust Company and David H. Jackman, President of the United States Corporation Company of New York. Jackman was the only non-Delawarian on the Commission and felt that he should have been excluded for that reason, but Secretary of State Dukes insisted. ${ }^{32} \mathrm{He}$ was there not only to represent the viewpoint of the corporation service companies, but also to give the viewpoint of the New Yorkers interested in Delaware's corporation law..$^{33}$ Rounding out the Commission were Daniel L. Herrmann, who later resigned to join the Delaware Supreme Court, ${ }^{34}$ and Mrs. Margaret Storey, then head of the Corporation Department in the Secretary of State's office and now Executive Vice President of the Corporation Service Company.

After the Commission was chosen, it was necessary to choose a Reporter. Ernest L. Folk, III, then Professor of Law at the University of North Carolina and now at the University of Virginia, was recommended by Collins J. Seitz, then Chancellor of Delaware's Court of Chancery. ${ }^{35}$ Professor Folk had already served as Reporter for South Carolina's corporation law revision ${ }^{36}$ and describes himself as being pro-management, although not rabidly so. ${ }^{37} \mathrm{He}$ was interviewed by

30 Id. 1782B-83B; see note 121 infra.

31 Id. $1769 \mathrm{~B}$.

32 Interview with David H. Jackman, in New York City, July 19, 1968 [hereinafter cited as Jackman Interview].

33 Id.

34 He was replaced by Clair J. Killoran, Esq., on February 10, 1965.

35 Interview with Richard F. Corroon, Esq., in Wilmington, Delaware, July 25, 1968 [hereinafter cited as Corroon Interview].

Judge Seitz was a man not without influence in Delaware and has since stepped up to the Third Circuit Court of Appeals. He was very popular with the Delaware Bar and the opinions he wrote in his 16 years on the bench were highly influential in shaping Delaware corporation law. When he appeared before the Senate Judiciary Committee for approval, James M. Tunnell, Chairman of the Delaware State Bar Association Committee on Judicial Appointments, testified: ". . . I do not have to tell anybody that we have a lot of lawyers in Delaware who would not mind being on the circuit bench. . . . But nevertheless, they were suppressed. . . . We had the unique experience of having the Bar stand shoulder-to-shoulder unanimously in support of Chancellor Seitz." Hearings Before Subcomm. of Comm. on the Judiciary of the Senate, Nomination of Collins J. Seitz of Delaware to be United States Circuit Judge, Third Circuit, Vice John Biggs, Jr., retired, April 5, 1966 19-20 (unpublished; on file at Senate Judiciary Committee Office, Washington, D.C.).

36 E. Folk, The New Delaware Corporation Law vi (1967).

37 Folk Interview, supra note 26. 
the Commission in March of $1964 ;^{38}$ at its third meeting, on March 20 , the Commission approved him, with only Jervis dissenting. ${ }^{39}$ Folk's assignment states, rather blatantly, the goal of the revision: "1. To take an overall survey of the statute so there would be no conflict between various sections; 2 . To ascertain what other states have to attract corporations that we do not have; 3 . What his recommendations would be for amending the law." 40 Completion date was set for September 1, 1964,"1 in the hope that "any amendments could be introduced at the next session of the legislature." 42

Several decisions were made quickly. The first problem was whether to scrap the existing statute and start over again or simply to amend and revise the present one. Arsht, possibly as a joke, suggested the use of Israel's statute as a model, since it is very simple, but Chief Justice Southerland evidently did not like the idea. ${ }^{43}$ The Commission decided to preserve as much of the present wording as possible so as to keep the body of precedents that had been built up over the years. ${ }^{44}$ This is not, of course, an unsound decision for a legislative draftsman to make. Statutes should be written to make their meaning as clear as possible, and using phrases which have already been interpreted furthers this goal. But the decision not to scrap the existing statute may have been made with other considerations in mind. A wealth of judicial decisions helps Delaware attract corporations; ${ }^{45}$ to do away with this body of precedent could very well lessen Delaware's salability. Thus the "comprehensive revision" of an 1899 bill began by rejecting thorough change of what can only be termed a tortured statute. ${ }^{46}$ Delaware began its business by borrowing New Jersey's wording so as to insure settled judicial interpretation, and it was not about to tamper lightly with part of the formula for its success.

For a similar reason, it was also decided that the revision should not follow the Model Act. ${ }^{47}$ The reason was stated simply by Mr. Jackman, President of the United States Corporation Company, who "emphasized that Delaware should not adopt the Model Act because we

$38 I d$.

39 See Minutes of the Delaware Corporation Law Revision Commission, 3d meeting, March 20,1964, at 1 (on file in offices of Morris, Nichols, Arsht \& Tunnell, Wilmington, Delaware).

40 Minutes of the Delaware Corporation Law Revision Commission, $2 \mathrm{~d}$ meeting, February 25, 1964, at 2 (emphasis added) (on file in offices of Morris, Nichols, Arsht \& Tunnell; Wilmington, Delaware).

41 Minutes $3 / 20 / 64$, supra note 39 , at 2 .

42 Minutes $2 / 25 / 64$, supra note 40 , at 2 .

43 Folk Interview, supra note 26.

44 Id. Since this has resulted in a statute which does not "read modern," Professor Folk thinks that some people believe the drafting job was not done properly, a criticism he feels to be unwarranted. Id.

$45 \mathrm{Jackman}$ Interview, supra note 32 . See text accompanying notes 243-46 infra.

46 See text accompanying note 82 infra.

47 ABA-ALI Model Bus. Corp. Act (1966). 
do not want to be a 'me too' state in view of the fact that in the past most of the other States had copied our laws and that we should be a leader not a follower." 48

It was then time to find out what the consumers might have to say. Or, more accurately, to find out what other consumers had to say, since the members of the Commission producing the law would also be using the finished product. Form letters were sent out, advising the recipient that a revision was in progress and soliciting comments on possible changes. ${ }^{49}$ Jackman wanted the letter "to publicize the serious effort being made to attract corporations". ${ }^{50}$ Judge Herrmann suggested that the letter advise law firms "of the reasonableness of Delaware taxes and fees applicable to corporations." 51 Professor Folk felt that the choice of recipients was not made on a systematic basis. "Essentially it boiled down to picking various firms which have had substantial contacts with Delaware and which have, of course, employed Delaware counsel to handle local litigations or other problems relating to the Delaware law." 52 Irving Morris suggested that three New York plaintiff's firms be sent letters: Pomerantz Levy Haudek \& Block, Shea, Gallop, Climenko \& Gould, and Milton Paulson. ${ }^{53}$ It is not known whether letters were ever sent to these firms, but no replies were ever received from them. ${ }^{54}$ Professor Folk observes that the lack of replies "reflects the fact that inevitably the drafting of the corporation law is aimed at the interests of the corporations themselves." 55

About 125 replies were received, although Professor Folk does not feel that they helped him significantly. ${ }^{56}$ Among the firms replying were Monroe \& Lemann, New Orleans; White \& Case, New York; General Foods Corporation; Ballard, Spahr, Andrews \& Ingersoll, Philadelphia; Drinker, Biddle \& Reath, Philadelphia; Cahill, Gordon, Reindel \& Ohl, New York; Faegre \& Benson, Minneapolis; Johnson, Bromberg, Ledes \& Riggs, Dallas; Cummings \& Lockwood, Stanford; and Deutsch, Garrington \& Styl, New Orleans. ${ }^{57}$

In addition to answering the form letters, lawyers sometimes inquired about specific provisions and a proposed draft would be sent

48 Minutes of the Delaware Corporation Law Revision Commission, 4th meeting, July 14, 1964, at 2-3 (on file in offices of Morris, Nichols, Arsht \& Tunnell; Wilmington, Delaware).

49 Corroon Interview, stspra note 35.

50 Minutes $7 / 14 / 64$, supra note 48 , at 2 .

51 Id. 1. While it is likely that these suggestions were incorporated into the letter, there is no way of being sure, since no copy could be located.

52 Letter from Professor Ernest L. Folk, III, July 17, 1968, at 1, on file at the Biddle Law Library, University of Pennsylvania [hereinafter cited as Folk Letter].

53 Morris Interview, supra note 22.

54 Folk Letter, supra note 52 , at 2 .

55 Id.

¿0 Folk Interview, supra note 26.

57 Folk Letter, supra note 52, at 1 . All the replies mentioned are on file at Professor Folk's office. 
to them for comment; sometimes firms would just write in suggestions. Thus the Commission's files contain letters from, for example, Johnson $\&$ Higgins, an insurance brokerage firm, ${ }^{58}$ Shell Oil Co., Cravath, Swaine \& Moore, and Reid \& Priest. 59

Other groups were also cultivated. Shortly after the Commission was organized, Corroon met with the Corporation Committee of the Association of the Bar of the City of New York, to inform them that a revision was underway. He also addressed them shortly before the bill was introduced into the legislature and before the full Commission had approved it. ${ }^{60}$ A copy of Folk's report and a draft of the law were also sent to them. ${ }^{61}$ The Delaware Bar Association was not treated as well. Its Corporation Law Committee normally handles revisions of the corporation law, but if there was any resentment at being preempted, it never surfaced. Corroon chairs the committee and he called only one meeting-to get their approval of the draft bill before they had read it. They got a little annoyed at this. ${ }^{62}$ There was also some dissatisfaction with the fact that the new statute would contain no explanation of the way in which the existing law would be changed, or the reasons for these changes. Omission of such explanations would put non-Commission lawyers at a disadvantage. Nevertheless, they approved the draft with one lone dissent. ${ }^{63}$ Corroon also discussed the provisions of the draft at a meeting of the Association of American Law Schools in Washington, D.C. Much to his surprise, the law professors had no questions to ask. ${ }^{64}$

The new statute was not written as rapidly as had been planned. ${ }^{05}$ The ten-member Commission proved unwieldy, so Chief Justice Southerland split up assignments among the members. A drafting committee of three was formed-Corroon, Canby, and Arsht. Through late 1966 and early 1967 they met to draft the actual statute, ${ }^{66}$ usually meeting on Saturdays in Arsht's office. ${ }^{67}$ Their job was far from mechanical. They considered many things the entire Commission never did, and felt they had broad authority and full responsibility. ${ }^{68}$

58 See note 167 infra.

59 These letters are on file in the offices of Morris, Nichols, Arsht \& Tunnell; Wilmington, Delaware.

60 Corroon Interview, supra note 35.

61 See Minutes of the Delaware Corporation Law Revision Commission, 7th meeting, December 15, 1964 (on file in offices of Morris, Nichols, Arsht \& Tunnell; Wilmington, Delaware).

62 Corroon Interview, supra note 35.

63 The dissenter was Bruce Stargatt. Folk Interview, stipra note 26.

64 Corroon Interview, supra note 35.

65 See text accompanying note 42 supra.

66 Folk Interview, supra note 26.

67 Interview with S. Samuel Arsht, Esq., in Wilmington, Delaware, July 24, 1968.

68 Corroon Interview, supra note 35. 
Although they rejected some of Folk's recommendations, ${ }^{60}$ and although he never attended any of their meetings, much of his wording was adopted in toto, a result which seems to frighten him. ${ }^{70}$

Since the product being manufactured is a law, the legislature (remember the legislature?) is supposed to have something to do with it. But it is clear that this was not the case. Simply stated, the Commission never expected the legislature to do anything with this law except pass it. ${ }^{71}$ One member of the Commission referred to the legislature as "just a bunch of farmers." Corroon did attend a caucus of Democratic Senators, and Canby did attend a caucus of Republican Senators. But Corroon was out in fifteen minutes, Canby in three, and neither was asked any questions about the law. ${ }^{72}$ The legislature did have one concern (besides tax revenues)-jobs. While it makes little sense to have certificates of incorporation filed with the Secretary of State and with county Recorders, ${ }^{73}$ to eliminate the Recorders would mean putting people out of jobs and the legislature might not have accepted that. ${ }^{74}$ So at the fourth meeting of the Commission, we find that "[i]t was moved by Mr. Jackman and seconded by Judge Herrmann that recordation as presently practiced should be continued . . . . 75 There is no evidence that the legislature had any other influence on the actual content of the law.

The bill was passed unanimously by the legislature and became effective on July 3, 1967; amendments were worked through their "normal" course, the Delaware Bar Association's Committee on Cor-

69 "I fully expected that many of the recommendations would not, for various policy reasons, be adopted; but I wanted the Committee to have the benefit of as wide a range of alternatives and ideas as I could supply." Ietter from Ernest L. Folk, III, to Richard F. Corroon, December 20,1966, at 1 (on file in offices of Morris, Nichols, Arsht \& Tunnell; Wilmington, Delaware). It is interesting to note some of the exotica investigated by Professor Folk. For example, a "foreign resident corporation" statute was drafted, which would have provided that "in time of war, invasion, international conflict, revolution, [or] other emergency" a foreign corporation could "emigrate" immediately to Delaware. See E. FolK, ReviEw of THE Delaware CoRporation LAw 294-322 (1965-1967) [hereinafter cited as ForK REPORT]. Bearer shares were also considered. Folk wrote in his Report: "First[,] in principle, the chief domicile of American corporations arguably should sanction a device which has proved useful in other parts of the world. Indeed, this may attract some extra-United States enterprises to seek Delaware incorporation, and would facilitate use of the Delaware Foreign Resident Corporation Act (if adopted)." Id. 288. Folk concluded, however, that "a general authorization of bearer shares would be undesirable." Id. 290 . Bearer shares were unanimously rejected by the full Commission. Minutes of the Delaware Corporation Law Revision Commission, 15th meeting, April 20, 1965, at 1 (on file in offices of Morris, Nichols, Arsht \& Tunnell; Wilmington, Delaware).

70 Folk Interview, supra note 26.

71 Corroon Interview, supra note 35.

72 Id.

73 See Dex. Code Ann. tit. 8, §103(b) (5) (Supp. 1968).

74 Jackman Interview, supra note 32.

75 Minutes of the Delaware Corporation Law Revision Commission, 4th meeting, July 14, 1964, at 3 (on file in offices of Morris, Nichols, Arsht \& Tunnell; Wilmington, Delaware). Folk strongly suggested abolishing local recordation (see FoLK REPORT, stpra note 69, at 1-2); his awareness of the problem comes out in one sentence: "It is recognized that local recordation may have to be continued for reasons not related to the advantage and convenience of corporations." Id. 2. 
poration Law, and became effective on January 2, 1968. There were no official documents explaining the statute's provisions, no legislative hearings, and no publications by the Revision Commission. Folk's Report, Review of the Delazuare Corporation Law, may not prove extremely helpful on key points and, in any event, it may be hard to find. The Commission originally made only one copy publicly available (in the New Castle County Law Library), ${ }^{76}$ but xerographic reproductions can now be bought from the Corporation Service Company for $\$ 25.00 .^{77}$ Despite the fact that the Commission had about $\$ 15,000$ left over, Secretary of State Dukes did not want to spend the money to reproduce the report. ${ }^{78}$ Thus, the participants are left free to write their own "legislative history," an invaluable opportunity for a lawyer. This can be done through writing books and articles "explaining" the law, ${ }^{79}$ or through argument in litigation. ${ }^{80}$

It is difficult to believe that the process just described represents the way legislation should be drafted. State legislatures may not be noted for thoroughgoing consideration of proposed bills, ${ }^{\mathrm{s1}}$ but the Delaware legislature's lack of concern seems extraordinary. The legislature simply abdicated its responsibility to consider the merits of its corporation law. It made no attempt to go outside the Commission and determine whether the statute served that "public interest" a legislature is supposed to represent. It was content to leave its work entirely to an appointed commission. It was content to leave this commission free to do what it pleased; and it pleased to solicit the views only of corporate interests and then to write a statute without one official word to guide future interpretation.

But correction of these procedural defects would not necessarily bring about changes in substance. Delaware measures its concern with corporation law in terms of tax revenues, and in this sense the legislature is representing the interests of Delawarians. This concern ought to lead Delaware to turn to the corporate lawyer for guidance, par-

76 Corroon Interview, supra note 35.

77 Letter from James M. Winfield, President, Corporation Service Company, Wilmington, Delaware, March 10, 1969, on file at the Biddle Law Library, University of Pennsylvania.

78 Corroon Interview, supra note 35 .

79 See, e.g., S. Arsht \& W. Stapleton, Analysis of the New Delaware Corporation LAW (1967) (published by the Prentice-Hall Corporation System, Inc.); E. Folk, The Red Book Digest of the New Delaware Corporation Law-1967 (1968) (published by the Corporation Service Co.) ; E. Folk, ThE NEw Delaware Corporation LAW (1967) (pubiished by the Corporation Service Co. and sold for \$2.00) ; Arsht \& Stapleton, Delaware's New General Corporation Law: Substantive Changes, 23 Bus. LAw. 75 (1967); Canby, Delaware's Neze Corporation Lawe, 39 PA. B. A. Q. 92 (1966). Mr. Stapleton is a partner in Morris, Nichols, Arsht \& Tunnell, and was a member of the Commission's legal staff.

80 Although Professor Folk felt that the lawyers on the Commission would not so use their position (Folk Interview, supra note 26), Morris said that one member had already done so. Morris Interview, supra note 22.

81 See Peck, The Role of the Contrs and Legislatures in the Reform of Tort Law, 48 Minn. L. Rev. 265, 275-77 (1963). 
ticularly those lawyers who represent the largest corporations. The corporation lawyer can make an honest claim to know what will attract corporations in the way of substantive law. Besides, who else could work with "that fantastic statutory pattern which we have come to know as corporation law, with its over-preoccupation with legal conceptions which grow into monstrous shapes as they feed upon themselves"? 82 Even if Delaware went through the full procedure of legislative hearings, who would one expect them to call? Perhaps countervailing groups-such as law professors, plaintiffs' lawyers, or consumers-would have appeared to oppose a liberal statute, although there is no evidence that these groups attempted to influence the Commission. If such groups were concerned, and had appeared, why should the legislature have listened to them? As the New Jersey Corporation Law Revision Commission noted in a preface to their 1968 revision, "[a]ny attempt to provide such regulations in the public interest through state incorporation acts and similar legislation would only drive corporations out of the state to more hospitable jurisdictions." ${ }^{83}$ Why should Delaware give up needed tax revenues in return for regulation that can be so easily circumvented?

In light of these factors, it is difficult to lay blame exclusively on the members of the Commission for writing a law designed to appeal to corporate interests. True, the Commission never thought in terms of public interest; or, more precisely, assumed that corporate interest and public interest are the same. But they did not believe they had done something unethical, or dishonest, or deceptive. They would not have opened their files so readily, or talked so frankly, had they felt they had something to hide. They all operated properly, well within the rules of the game. This, after all, is the way Delaware has written its corporation law since 1899 , and the members of the Commission were not chosen to correct the drift, had they perceived correction to be necessary. Nobody on the Commission, and nobody with whom the Commission talked, was about to suggest that perhaps the game was no good. As Professor Latty wrote, "[y]ou do not find beatniks on corporation law committees." 84

Nor does the blame for selling corporation law lie exclusively with Delaware. Perhaps other State legislatures do not have their corporation laws written for them to the extent that Delaware does, but this matters only indirectly. So long as there are national corporations, for whom state domicile is only a legal concept, there is bound to be at least one state which will seek out their business. Delaware has been one of the states that traditionally have done so. Its law will

82 Latty, Why Are Business Corporation Laws Largely "Enabling"?, 50 CoRAELL L. Q. 599, 619 (1965).

83 N.J. Rev. Stat. \$14A, at XI (1969). See Investigation of Concentration of Economic Power; Final Report and Recomimendations of the TEMPORARY National Economic Committee, S. Doc. No. 35, 77th Cong., 1st Sess. 28 (1941).

${ }^{84}$ Latty, supra note 82, at 616. 
either be copied-forcing Delaware to go further-or Delaware will get most of the business. In either event Delaware will be writing a national corporation law.

\section{The Statute}

It now becomes necessary to examine the product, which, not surprisingly, makes only the weakest attempt at restricting the corporation. $^{85}$ Section-by-section analysis will not be attempted; rather, the discussion will concentrate on several important provisions.

It is the managers of the corporation who will usually be buying the law, so an obvious way to attract business is to limit the shareholders' rights. How far this idea can go may be seen in section 211(b), which, as originally passed in 1967, had provided that at the annual shareholder meeting to elect directors, "any other proper business notice of which was given in the notice of the meeting, may be transacted." 86 Since notice of the meeting is sent out by management, ${ }^{87}$ this would have meant that shareholders could not discuss at the meeting any questions management did not wish to discuss. ${ }^{88}$ This was just too much of a perversion, even for Delaware; ${ }^{89}$ the statute was amended to allow transaction of "any other proper business." 90 But a provision allowing shareholders to put questions for discussion in management's notice of the meeting was never considered-it would have been improper in a management-oriented statute. ${ }^{91}$ Shareholders are also not allowed to propose amendments to the corporation's charter; amendments must originate by a resolution of the board of directors. ${ }^{92}$ So, to change the charter, shareholders must first change (or persuade) the management.

In the merger area, shareholders are denied appraisal rights if the corporation is registered on a national securities exchange or if its

85 Another example of the lack of restriction on corporate activity in Delaware is the lack of any Blue Sky Law. This is a good selling point; the Corporation Service Co. places it third on its list of twenty-five "advantages of the Delaware law." The list is printed in, e.g., E. FOLK, THE RED BOOR DIGEST OF THE NEW Detaware Corporation Law-1967 iv (1968). According to Morris, stock fraud in Delaware is investigated by Col. Lamb of the State Police. Morris Interview, supra note 22.

86 Law of July 3, 1967, v. 56, ch. 50 [1967] Del. Laws 185 (repealed 1968).

87 See DeL. Code ANN. tit. 8, §222 (Supp. 1968).

88 This provision, of course, would not have limited the shareholders' Federal right to have management include in the proxy statement a shareholder proposal which would be voted on. See SEC v. Transamerica Corp., 163 F.2d 511 (3d Cir. 1947), cert. denied, 332 U.S. 847 (1948).

89 Interview with Henry Canby, Esq., in Wilmington, Delaware, July 25, 1968 [hereinafter cited as Canby Interview].

90 Dec. Code Ann. tit. 8, §211 (b) (Supp. 1968).

91 Folk Interview, supra note 26.

92 See Del. Code ANN. tit. 8, §242(d) (1) (Supp. 1968). 
stock is held by more than 1999 shareholders. ${ }^{93}$ This should effectively eliminate appraisal rights in a fair number of corporations. The shareholder who has appraisal rights and wishes to preserve them, must file his objection to the merger before the vote is taken, and may not vote in favor of the merger; ${ }^{94}$ but the notice the corporation must send informing shareholders of a merger vote need not tell the shareholders how to preserve their appraisal rights, or even that they have any such rights. ${ }^{95}$ And if the shares to be issued or delivered under the plan of merger do not exceed fifteen per cent of the shares of the same class of the surviving corporation, shareholders of the surviving corporation do not even have the right to vote on the merger. ${ }^{96}$ Professor Folk wrote in his Report that the fifteen per cent procedure "could be abused by successive mergers with various corporations, no one of which involved an issue of more than $15 \%$ of the previously outstanding shares." Nevertheless, he concluded that "this Report sees no fundamental objections to the proposed procedure; and if it would reasonably serve business interests, it should be adopted." ${ }^{97}$ No doubt, easier merger provisions will serve business interests in today's mergerconscious economy. ${ }^{98}$

Financial plums are also offered to managers. Section $122(15)$ empowers the corporation to "establish and carry out pension, profit sharing, stock option, stock purchase, stock bonus, retirement, benefit, incentive and compensation plans, trusts and provisions for any or all of its directors, officers, and employees ...." 99 The previous

03 See id. $\$ 262(\mathrm{k})$. Professor Folk writes that "West Virginia is the only state which has no appraisal rights, apparently the relic of an abortive effort long ago to attract corporations." FOLK REPORT, supra note 69, at 196 n.1. The implication is clear that denial of this right to shareholders will be attractive to corporations. This was not quite done in Delaware, evidently because of the fear that courts might more easily disapprove "unfair" mergers if the shareholders had no alternative remedy. Corroon stated that $\$ 262(\mathrm{k})$ has been criticized by lawyers for this reason; he does not agree that the section will have such an effect. Corroon Interview, supra note 35 .

04 See Der. Code ANn. tit. 8, \$262(b) (Supp. 1968).

95 See id. $\$ 251(\mathrm{c})$.

${ }^{06} S e e$ id. $\$ 251(f)(2)$. The $15 \%$ provision was suggested to Canby by Dewey, Ballantine, Bushby, Palmer \& Wood. FoLK REPORT, supra note 69, at 195A. Professor Folk, in THE NEw DELAwARE Corporation LAW 32 (1967), wrote that this type of merger is "not such a major change as to require a shareholder vote or appraisal rights"; in his Report, however, he did suggest that a $10 \%$ figure would be "more conservative." See FolK REPORT, supra note 69, at $195 \mathrm{~B}$.

97 FolK REPORT, supra note 69, at 195A, 195B (emphasis added).

98 For example, Royal Industries, in explaining to its shareholders the reasons for moving to Delaware, wrote: "In particular, recent revisions of the Delaware corporation law will add flexibility to the Company's acquisition program by permitting companies which are substantially smaller than the Company ... to be acquired by merger without the approval of the Company's stockholders. . . . Dissenting stockholders of the Company are presently entitled under California law to receive payment for their shares in connection with a merger or consolidation. Stockholders of Royal Delaware [the "new" corporation] will not have any such right so long as its shares are listed on the American Stock Exchange or any other national securities exchange." Notice of Annual Meeting of Shareholders, March 29, 1968, at 7 (on file at the Securities \& Exchange Commission, Washington, D.C.).

${ }^{99}$ Dez. Code ANN. tit. 8, §122(15) (Supp. 1968). 
statute had not expressly conferred this power, but the new statute makes no attempt to set any procedures for management to follow so as to prevent possible abuses. There is not even a provision to require disclosure of the amounts paid. One would think that the shareholders might want to know whether, for example, they are paying directly for the college education of an officer's child. For, according to Professor Folk, " $[t]$ his language is sufficiently broad to permit financial aid to dependents of corporate personnel as an aspect of compensation, pension and incentive arrangement for employees." 100 Then there is section 143, which permits the corporation to make loans to officers or employees, as long as the board of directors judges that the loan may reasonably be expected to benefit the corporation. ${ }^{101}$ The board may give the loan without interest and without security-and again there is no provision for disclosure to shareholders. ${ }^{102}$

Professor Folk wrote in 1966: "The aid-to-directors movement has now so exhausted itself in an orgy of indulgence and favoritism that little more remains to be done on the state level." ${ }^{103}$ But Professor Folk was wrong. Much remained to be done, and in 1967 Delaware did it with the passage of section 145 -indemnification. ${ }^{104}$

There had been considerable criticism of the old indemnification provision, section 122(10). ${ }^{105}$ Arsht writes: "Neither the courts nor corporate counsel found the language of this statutory provision wholly satisfactory . . . and numerous charter and by-law provisions were adopted in an attempt to clarify and extend the statutory power of indemnification." 106 The second sentence of the old section was so broad that "uncertainty existed in many instances as to whether such provisions transgressed the limits which the courts had indicated they

100 E. Folk, The New Deiaware Corporation Law 9 (1967). According to Folk, such aid was already being granted under the old statute. Folk Interview, supra note 26.

101 Del. Code Ann. tit. 8, §143 (Supp. 1968).

102 Id. Professor Folk felt that $\$ 143$ was overly liberal. Folk Interview, supra note 26.

103 Folk, Corporation Statutes: 1959-1966, 1966 Duke L.J. 875, 889.

104 Dex. Code ANN. tit. 8, $\$ 145$ (Supp. 1968). On the subject of indemnification, see generally $\mathrm{G}$. Washington \& J. Bishop, Indemantrying the CoRporate ExecuTIVE (1963).

${ }^{105}$ Law of April 15, 1943, v. 44, ch. 125 [1943] Del. Laws 422 (repealed 1967).

Section $122(10)$ provided:

Every corporation ... shall have power to ... [i]ndemnify any and all of its directors or officers ... against expenses actually and necessarily incurred by them in connection with the defense of any action, suit or proceeding in which they ... are made parties ... by reason of being or having been directors or officers ... of the corporation ... except in relation to matters as to which [they] ... shall be adjudged . . . liable for negligence or misconduct in the performance of duty. Such indemnification shall not be deemed exclusive of any other rights to which those indemnified may be entitled, under any by-law, agreement, vote of stockholders, or otherwise.

$106 \mathrm{~S}$. Arsht \& W. Stapleton, Analysis of the New Delaware Corporation LAw 327 (1967) (emphasis added). 
would establish based on public policy." 107 But the new provision was not written simply out of a desire to clear up ambiguous language; at root, the motivation was the increasing fear of financial liability. An address to the Association of General Counsel in 1966-a copy of which is in the Commission's files-relates:

I have noticed in the last year or so that it [indemnification] has become a very "hot" item. Taking my own office as an example, I have been personally involved or consulted by my partners on this subject as applied to at least a dozen different corporations in the last year-and I might add it is still going on. I suppose the highly publicized situations, with potentially astronomical exposure for the individuals involved-I have in mind the Philadelphia electric antitrust cases, American Express and the Salad Oil machinations, Bill Sol Estes and his grain elevators and others-have had a good deal to do with the current interest. ${ }^{108}$

Certainly most officers and directors would think indemnification improper in the examples given, but these examples do indicate the presence of corporate fear and the direction of corporate desires for indemnification.

The argument favoring indemnification was stated simply in 1966 by Orvel Sebring, then Chairman-Elect of the ABA Section on Corporation, Banking and Business Laws, and a member of the Section's Committee on Corporation Laws: "[Indemnification] is good social policy . . . because we must get the best men available to run our corporations. The lifeblood of business depends upon the quality of guidance which officers and directors can give the corporations. So there is a strong case for indemnification." ${ }^{109}$ The American Bar Association has made such arguments before in connection with indemnification. When the Securities and Exchange Commission held hearings on Note (a) to Rule 460 - which provides that indemnification for liabilities arising under the Securities Act of 1933 either be waived or submitted to a court for approval ${ }^{110}$ _John Mulford, Esq., testified as to the ABA's opposition. In response to arguments similar to Sebring's, Chairman Armstrong stated: "I have just great difficulty in believing that the American Corporations would be unable to continue

107 Arsht \& Stapleton, Delazuare's New General Corporation Law: Substantive Changes, 23 Bus. LAw. 75, 78 (1967). See Essential Enterprises Corp. v. Dorsey Corp., 40 Del. Ch. 343, 357, 182 A.2d 647, 655-56 (1962) (Seitz, C., suggests legislature clarify $\$ 122(10))$.

108 Address by Royal Victor to Association of General Counsel, Clayton, Mo., October 20, 1966, at 2 (on file in offices of Morris, Nichols, Arsht \& Tunnell; Wilmington, Delaware).

109 Sebring, Symposinm: Duties and Liabilities of Corporate Directors, 22 Bus. LAw, 29, 124 (1966).

110 See 17 C.F.R. $\$ 230.460$, note $a$ (1957); id. $\$ 230.460$ (a) (1954). 
the services of acceptable directors." ${ }^{111}$ That was 1957, and there is as yet no evidence that qualified persons have been deterred by the requirement. But the rhetoric lingers on and we find even General Motors claiming that broad indemnification "is considered appropriate . . . from the standpoint of enabling the Corporation to continue to attract and retain those best qualified for service as directors and officers." 112 Officers and directors may feel they are being treated more equitably if they can be indemnified for liabilities arising from corporate duties, and this may be good social policy in certain situations. But it is difficult to believe that someone will be deterred from becoming an officer of a corporation like General Motors simply because he may some day be sued.

The pressure for broad indemnification could not be resisted. Large corporations were busy revising their indemnification by-lawsBethlehem Steel in 1964, Firestone, Goodyear, Monsanto and Standard Oil of New Jersey in 1965, International Harvester, Southern Pacific and Texaco in 1966.113 A liberal indemnification provision would be a good selling point and without something more explicit than section $122(10)$, counsel could not be sure that an award of indemnification would obtain judicial approval if it ever came to litigation. What the consumers received, and how they got it, is worth analysis. ${ }^{114}$

Subdivision (a) of section 145 empowers the corporation to indemnify directors, officers, employees or agents of the corporation for actual and reasonably incurred expenses (such as attorney's fees), judgments, fines and amounts paid in settlement. It applies to administrative or investigative proceedings ${ }^{115}$ and all criminal or civil suits, other than derivative actions, which grow out of a person's official capacity. To be indemnified, the party must have acted "in good faith" and "in a manner he reasonably believed to be in or not opposed

111 Hearings on Proposed Note to Rule 460 before the Securities \& Exchange Commission, January 17, 1957, at 28 (on file at the Securities \& Exchange Commission, Washington, D.C.).

112 General Motors Notice \& Proxy Statement for May 19, 1967, Shareholder Meeting, at 24 (on file at the Securities \& Exchange Commisssion, Washington, D.C.).

113 Address by Royal Victor, supra note 108, at 7-8.

114 Not everyone condemned retention of $\$ 122(10)$. For example, a June 22 , 1966 letter from Cravath, Swaine \& Moore to the Commission stated that they felt $\$ 122(10)$ was fine, that they did not know of any "serious problems" or "abuses" under it, and that the new $\$ 145$ would cut down its coverage (at 2) (on file in offices of Morris, Nichols, Arsht \& Tunnell, Wilmington, Delaware).

115 Arsht writes that one of the reasons for revising section $122(10)$ was the "unjustifiable narrowness of classes of persons to whom money could be paid and types of proceedings." Arsht \& Stapleton, supra note 107, at 78. Thus subdivision (a) tries to include everyone, except shareholders, and every type of proceeding, including investigations that have nothing to do with adjudication. Oddly enough, appeals are not specifically covered, but there is little doubt that judicial construction could find that the legislature "intended" to include them. Professor Folk felt they were meant to be included. Folk Interview, sipra note 26 . But the competing New Jersey indemnification provision takes no chances; appeals are specifically covered. See N.J. Rev. Stat. tit. 14A, §14A:3-5(1) (e) (Supp. 1968). 
to the best interests of the corporation"; ${ }^{116}$ in a criminal case, the defendant must also have had "no reasonable cause to believe his conduct was unlawful." But the termination of any action "by judgment, order, settlement, conviction, or upon a plea of nolo contendere or its equivalent, shall not, of itself, create a presumption" that the person did not act in accordance with the requisite standards.

The first important thing to note about subdivision (a) is that it is an example of enablingism-the State enables management to fill out the corporation law in the way it feels best. ${ }^{117}$ Enabling provisions recognize that a general corporation law, if drawn too specifically, may not be well suited for all corporations. ${ }^{118}$ Thus the State avoids making policy decisions that may force an expansion or limitation of corporate powers in ways not agreeable to all corporations. Here, the corporation is given discretion in deciding whether to award indemnification; management can still give itself a right to indemnification, by properly wording its charter or indemnification by-law. ${ }^{110}$ Mr. Jackman's United States Corporation Company, in a handy pamphlet titled Delaware Corporation Forms, suggests the following for prospective clients' certificates of incorporation: "The Corporation shall, to the full extent permitted by Section 145 of the Delaware Corporation Law, as amended from time to time, indemnify all persons whom it may indemnify pursuant thereto." ${ }^{120}$ General Motors, in Article 31 of their by-laws, is likewise quite specific in giving a right of indemnification to parties who have fulfilled the standards set out in subdivision (a).$^{121}$

116 Det. Code Ann. tit. 8, \$145(a) (Supp. 1968) (emphasis added).

117 For some other examples of enablingism, see DEL. CODE ANN. tit. 8, §102 (b) (3) (pre-emptive rights granted only to the extent given in certificate of incorporation), $\$ 109$ (a) (shareholders have power to make, alter or repeal by-laws, but certificate of incorporation may confer powier on directors), \$212 (a) (unless provided in certificate of incorporation, each shareholder entitled to one vote for each share), $\$ 214$ (certificate of incorporation may provide for cumulative voting), \$216 (certificate of incorporation or by-laws may specify votes necessary for a quorum or to transact business), $\$ 242$ (a) (4) (accrued, but unpaid, dividends on preferred stock may be cancelled by amending certificate of incorporation).

118 Delaware recognizes this to some extent in its special provisions for close corporations. See Dez. Code ANN. tit. 8, \$\$ 341-355 (Supp. 1968).

119 It would probably be safer to put it in the charter; by-laws can be amended by the shareholders, but the charter cannot. See Der. CodE ANN. \$109(a) (Supp. 1968); note 92 supra and accompanying text. added).

120 U. S. Corporation Co., Delaware Corporation Forms 9 (1967) (emphasis

121 See General Motors Notice \& Proxy Statement for May 19, 1967 Shareholder Meeting, at 40 (on file at the Securities \& Exchange Commission, Washington, D.C.). The history of General Motors' new by-law is interesting. The by-law was adopted by the Board of Directors on November 7, 1966, effective immediately but subject to shareholder approval. See Form 8-K, filed pursuant to $\$ 13$, Securities Exchange Act of 1934, Report for November 1966 (on file at the Securities \& Exchange Commission, Washington, D.C.). Wording of the by-law bore a striking resemblance to $\$ 145-$ which was not passed by Delaware until July 3,1967, a full \& months later. In its notice for the May, 1967, meeting, General Motors informed its shareholders that, in the opinion of its Delaware counsel, the by-law was legal. Notice \& Proxy Statement, sipra, at 24. This may have been true, since no one really knew what $\$ 122(10)$ meant. General Motors' Delaware counsel's assurance 
The second important point is that a director may be indemnified if he reasonably believed his actions were "not opposed to the best interests of the corporation." Neither the original draft of section 145 submitted by Folk, ${ }^{122}$ nor a draft prepared by Corroon, ${ }^{123}$ had this provision. According to Corroon, the sentence was added to reach good faith takings of corporate opportunities ; ${ }^{124}$ if an officer or director takes a corporate opportunity in good faith, he would certainly think his actions were not opposed to the best interests of the corporation. It is arguable, however, that insider trading would also be "not opposed to" the corporation's best interests. ${ }^{125}$ The latter construction had not occurred to Corroon ${ }^{126}$ - despite the fact that he had been given the responsibility for drafting the indemnification provision. ${ }^{127}$ Others had no such doubts. Arsht writes: "The phrase 'or not opposed to' was included to cover the case where a director is engaged in a purely personal transaction, such as a purchase or sale for his own account of stock of the corporation . . . ." 128 Orvel Sebring, when discussing the Model Business Corporation Act's new indemnification provision,

may be explained by the fact that they knew what $\$ 145$ would provide-their counsel is Richards, Layton \& Finger, one of whose partners is Henry Canby.

We might note that General Motors did not have to submit this by-law to its shareholders, since G.M.'s by-laws allow unilateral amendment by the Board. See General Motors By-laws, June 5, 1967, Article 69 (on file at the Securities \& Exchange Commission, Washington, D.C.). But getting shareholder approval seems to be in conformity with advice given in an address to the Association of General Counsel: "Stockholder approval precludes successful challenge to the provision on the ground that it was adopted by a board of directors in conflict with the best interests of the corporation." Address by Royal Victor, stpra note 108, at 18. G.M.'s faith in its shareholders was not misplaced-223,933,951 votes were received in favor of ratification, or $99.0 \% ; 2,311,466$ votes opposed, or $1.0 \%$. See Nader, General Motors Corp.: Distribution of Ownership and Ability of Management to Gain Overwhelming Proxy Support for Position it Urges, in Hearings Before the Sen. Subcomms. of the Select Comm. on Small Business, 90th Cong., 2d Sess. 107 (1968) [hereinafter cited as Hearings]. The figures on other General Motors proxy votes further confirm the easy time that the management of a large corporation has with its shareholders. From 1962 through 1967, the smallest percentage received for management proposals was $98.4 \%$ of the vote cast (proposals relating to employee pension and stock option plans); the largest percentage received for a shareholder proposal was $5.3 \%$ of the vote cast (proposal to limit executive compensation to $\$ 200,000$ per year). Id.

122 See Folk Report, supra note 69, at 94.

123 See Memorandum from Richard F. Corroon to the Commission, November 13, 1964 (on file in offices of Morris, Nichols, Arsht \& Tunnell; Wilmington, Delaware) [hereinafter cited as Corroon Memorandum]. Chief Justice Southeriand had assigned Corroon the task of drafting an indemnification provision. Minutes of the Delaware Corporation Law Revision Commission, 5th Meeting, August 13, 1964, at 2 (on file in offices of Morris, Nichols, Arsht \& Tunnell).

124 Corroon Interview, supra note 35.

125 See A. Berle \& G. Means, The Modern Corporation and Private Property 223-24 (1933); H. MANNe, INSIDER Trading AND the Stock Market (1966). . But see Mendelson, Book Review, 117 U. PA. L. Rev. 470 (1969); Schotland, Unnsafe At Any Price: A Reply to Manne, Insider Trading and the Stock Market, 53 VA. $\mathrm{L}$. Rev. 1425, 1452 (1967); cf. Brophy v. Cities Service Co., 31 Del. Ch. 241, 70 A.2d 5 (1949); Diamond v. Oreamuno, 29 App. Div. 2d 285, 287 N.Y.S.2d 300 (1968).

126 Corroon Interview, supra note 35.

127 See note 123 supra.

128 S. Arsht \& W. Stapleton, supra note 106 , at 327. 
which is an exact duplicate of Delaware's, ${ }^{129}$ writes: "The words 'or not opposed to, the best interests of the corporation' were inserted to cover the possibility of a case . . . based on acts in an individual capacity such as were involved in the Texas Gulf Sulphur case." ${ }^{130}$ Professor Folk agrees with this interpretation and he opposed including the phrase. ${ }^{131}$ It is bad enough to indemnify a director or officer who, even in good faith, took a corporate opportunity-to do so is to allow him to keep profits that belong to the corporation. But to allow him to retain profits from insider trading sounds like a direct evasion of federal law.

The next important point is the combination of the phrase "no reasonable cause to believe his conduct was unlawful" 132 with the "nonpresumption" clause. Losing a suit-or even being convicted and fined in a criminal prosecution-does not necessarily mean that indemnification will not be made for the amount paid in judgment or fine. Professor Folk explains the policy underlying such a provision: "The theory is that an act may be contrary to the interests of the state, but it is not for that reason alone a breach of duty to the corporation or even against the best interests of the corporation." 133 Of course, the convicted criminal must have had no reasonable cause to believe his conduct was unlawful; as an example, Professor Folk writes that a convicted price-fixer could make no such claim, since everyone knows that price-fixing is clearly illegal. ${ }^{134}$ But what of the convicted pricefixer who contends, not that price-fixing is legal, but that he never performed the acts in question? Perhaps on a plea of guilty no one could make such an argument with a straight face; but on a plea of nolo contendere, and particularly on a guilty verdict after a jury trial, the argument could be made. This possibility was evidently never seen by the draftsmen of section 145; Professor Folk had to admit that indemnification could indeed be granted in such circumstances. ${ }^{135}$ In other words, Delaware law may purport to make it possible to have

129 See ABA-ALI Modec Bus. Corp. Act § 4A (Supp. 1967).

130 Sebring, Recent Legislative Changes in the Law of Indemnification of Directors, Officers and Others, 23 Bus. LAw. 95, 102 (1967). As of June 1968, the SEC had not expressed any position on indemnification in insider trading situations. One staff member stated, however, that in his view where the relief granted was to return the insider's profits to the corporation, the re-return of the money to the insider would be rather anomalous. Interview with Donald Feuerstein, Esq., General Counsel's Office, Securities \& Exchange Commission, in Washington, D.C., June $12,1968$.

131 Folk Interview, supra note 26.

132 A December 15, 1966 letter (page 2) from W. F. Kenney, Vice President and General Counsel of Shell Oil Co., to Henry Canby suggested putting in this clause (on file in offices of Morris, Nichols, Arsht \& Tunnell; Wilmington, Delaware) [hereinafter cited as Kenney Letter]. Folk's draft did not include the phrase. See FOLK REPORT, sipra note 69 , at 94-96. added).

133 E. Folk, The New Delaware Corporation Law 12-13 (1967) (emphasis

134 Id. 12.

135 Folk Interview, supra note 26. 
fines paid by the corporation, rather than by the officer or director convicted of violating a criminal statute.

Subdivision (b) deals with derivative actions. It empowers the corporation to indemnify the same group of people, under the same mental standards, as in subdivision (a). There are two differences: (1) the party can only get expenses incurred in a defense or settlement; and (2) if he has been "adjudged to be liable for negligence or misconduct in the performance of his duty to the corporation," he can only get indemnification for "such expenses" as the court may deem proper. ${ }^{136}$

There was some controversy over what subdivision (b) should cover. After all, what would bring more joy to an officer or director than to eliminate the worry of liability in stockholder suits? But it was evidently too unpalatable to treat an officer or director who lost a derivative suit in court in the same fashion as one who lost any other type of suit in court. Professor Folk wrote in his Report: "Since the [derivative] action produced a corporate recovery for breach of duty, a repayment to the faithless person of all his expenses plus the judgment against him would defeat the purpose of the original action and its subversion of fiduciary duty enforcement would probably be against public policy." 137

So a more subtle way of insulating management from responsibility was sought-full indemnification of out-of-court settlements. While the settlement itself is judicially supervised, ${ }^{138}$ the granting of indemnification would not be. It was the American Bar Association people responsible for drafting the Model Business Corporation Act who wanted this provision. They had been working on a redraft of their indemnification provision for about two years and had sent a copy to the Delaware Commission. To Willard Scott, Chairman of the ABA Committee on Corporate Laws, which is responsible for the Model Act, full indemnification of settlements is a wonderful idea. After all, by indemnifying the officer or director when he settled, settlements would obviously be encouraged; this would save the corporation money, since high legal fees would not be run up by going to trial. ${ }^{139}$ One must

136 The only construction problem is the meaning of "such expenses." May the amount the defendant has paid to the corporation by way of judgment be returned to him by the court? Or does "such expenses" mean only such things as lawyer's fees? Arsht writes that the provision "is intended primarily to deal with the case where no bad faith was involved and the type of conduct for which liability was imposed had not been previously determined to be wrongful." S. Arsht \& W. STAPLEToN, supra note 106 , at 328 . This would seem to indicate that "such expenses" can mean everything the defendant had to pay out. Professor Folk, however, feels that indemnification of judgments is probably not covered. Folk Interview, supra note 26 ; cf. E. Folk, THe New Detaware Corporation Law 13 (1967). His construction takes some strength from the fact that in subdivision (a), "expenses" is differentiated from "judgments" and "amounts paid in settlement."

137 Folk Report, supra note 69, at 86.

138 See DeL. CH. CT. R. 23(c).

139 Scott Interview, supra note 23. 
wonder, however, how many derivative suits would ever get to trial if a guilty officer or director could avoid paying anything by simply settling out of court. But then, as Professor Folk, and others, have noted, the "Model" Act is "not known for its restrictive attitude towards management." 140

Even Delaware could not accept Scott's position. Professor Folk wrote in his Report: "Uncontrolled indemnification of settlement derivative suits . . . . [b]y promoting settlement of claims which cannot be successfully defended . . . undercuts enforcement of fiduciary duties." 141 Not that the Model Act people did not try to convince the Commission. Two Philadelphia lawyers, Orvel Sebring and Carroll Wetzell, were sent down to Wilmington to discuss it with the drafting committee of Canby, Corroon and Arsht. ${ }^{142}$ When that failed, they withdrew their proposal "in the interests of harmony" and adopted Delaware's new statute, almost word for word. ${ }^{143}$ Sebring states what now seems to be the "official" position of the Model Act: "Although it may be argued that to permit indemnification of settlement payments under a strict standard of conduct might lessen the cost of litigation to be borne by the corporation, the result would be confusing and would nullify the derivative action to a large degree." 144

Folk's proposed statute would have gone in the opposite direction-indemnification of expenses in settled derivative suits would have to be approved by Chancery. ${ }^{145}$ But Corroon opposed this, feeling it would be stricter than section $122(10),{ }^{146}$ and Delaware was certainly not about to get any stricter. Thus the present statute emerged-for out-of-court settlement, return of expenses; for adjudicated liabilities, return only of such expenses as the court shall approve. ${ }^{147}$

Subdivision (c) is relatively straightforward. It gives the defendant who has been successful "on the merits or otherwise" in any suit or proceeding mentioned in (a) and (b) a right to be indemnified. W. F. Kenney, Vice President and General Counsel of Shell Oil Company, expressed his dissatisfaction with this in a letter to Henry Canby: "I think 'or otherwise' should be stricken. A corporation should not be required to indemnify a crook merely because he was

140 Folk, Revisiting the North Carolina Corporation Laze: The Robinson Treatise Reviezved and the Statute Reconsidered, 43 N.C. L. REv. 768, 841 (1965). See, e.g., Latty, supra note 82, at 615; cf. Katz, The Philosophy of Midcentury Corporation Statutes, 23 LAW \& ContenP. ProB. 177, 188 (1958).

141 FOLK REPORT, supra note 69, at 89.

142 Scott Interview, supra note 24.

143 Id. In fact, they accepted it so completely that an early draft of the Model Act even referred to the "Court of Chancery" in subdivision (b). Folk Interview, stipra note 26.

144 Sebring, supra note 130 , at 103. It must be noted, however, that, as of July 1968, Scott seemed unconvinced. Scott Interview, supra note 23.

145 See FolK REPORT, supra note 69, at 95-96.

146 See Corroon Memorandum, supra note 123.

147 Professor Folk feels that this provision will still have the effect of encouraging settlements. Folk Interview, silpra note 26. 
successful on some technical defense." ${ }^{148}$ But the phrase was not removed.

Subdivision (d) is either very subtle or badly drafted. Subdivisions (a) and (b) provide that a party must meet certain mental standards if he is to be indemnified; subdivision (d) provides the method for deciding whether the party has met these standards. The decision may be made by a majority vote of a quorum of directors not parties to the suit; if such a quorum cannot be obtained, or if the quorum so directs, the decision may be made by independent legal counsel, or the decision may be made by the shareholders.

It is likely that the decision-makers will be favorable to the party seeking indemnification. For one, courts are not mentioned. ${ }^{149}$ For another, it is difficult to see how management can ever be truly "disinterested"; the directors who vote today may be voted on tomorrow. The board may, however, prefer to have "independent counsel" make the decision, to give the appearance of removing any conflict of interest. ${ }^{150}$ In fact, this is precisely what General Motors did in its recent by-law. ${ }^{151}$ But there is no standard for independence in the statute. Professor Folk stated that house counsel or ordinary outside counsel would probably not be considered "independent"; a reputable law firm, such as Covington \& Burling of Washington, D.C., if it was not normally used as outside counsel, would probably be considered independent. As to what would happen if such a law firm began to do a large volume of this work, Professor Folk had no answer. ${ }^{152}$

The question of independence points up the difficulty of judicial review of these awards. The court is given no mandate to see whether "independent" legal counsel has made the correct decision, for that would make the use of such counsel meaningless; rather, the court can only determine whether counsel was, in fact, independent. Can a court know whether counsel was picked because management felt it would be favorable (possibly because such counsel had decided favorably in other cases), or because management truly desired impartial counsel ? ${ }^{153}$ No.

148 Kenney Letter, sipra note 132 , at 1.

149 Judge Seitz wanted Chancery also to be able to authorize indemnification; Corroon opposed this. Corroon Memorandum, supra note 123.

$150 \mathrm{Cf}$. note 121 supra.

151 See General Motors Notice \& Proxy Statement, stipra note 121, at 40. It must be noted that G.M.'s by-law gives the award as of right when independent counsel finds the requisite standards have been fulfilled; the Board of Directors still retains the discretion to award indemnification if counsel does not so find. Id.

152 Folk Interview, supra note 26. Professor Joseph W. Bishop notes that Westinghouse, in its by-law, has provided for "regular counsel of the corporation." Bishop, Sitting Ducks and Decoy Ducks: New Trends in the Indemnification of Corporate Directors and Officers, 77 Y ALE L.J. 1078, 1080 n.7 (1968).

153 "[T] he problem . . . is that those who choose them [independent counsel] are pretty sure to favor a lawyer who has acquired in the course of a corporate practice a sympathetic understanding of the problems of corporate management. It is not easy for even a lawyer of the most rugged integrity to be harsh to people who were responsible for his retainer." Bishop, supra note 152 , at 1080 . 
But the board of directors' decision will not be any easier to review. In court its decision will be protected by the sound business judgment rule; the convicted price-fixer is free to convince the board that he did not do what he had been found guilty of ${ }^{154}$ and the court will only be able to inquire whether the board was "disinterested," a difficult task at best. Then there is always shareholder approval. One must question how shareholders are to evaluate whether the officer or director acted in "good faith" or whether he reasonably believed his actions were "in or not opposed to the best interests of the corporation," or whether he had "no reasonable cause to believe his conduct was unlawful." Presumably management will write a narrative of the events and recommend conclusions for the shareholders to draw. The ease of getting shareholder approval, particularly in a large corporation, is hard to overestimate. ${ }^{165}$

Subdivision (e) may be treated briefly. It is a "pay-as-you-go" provision, empowering the board to advance expenses to the defendant upon receipt of an "undertaking" that he will repay them unless he is later found to be entitled to indemnification. ${ }^{156}$ "Undertaking" is not defined in the statute, but Professor Folk states that it need be nothing more than a promise to repay. ${ }^{157}$

It has been pointed out that the original impetus for rewriting old section 122(10) was its vagueness. Under particular fire was the lack of guidance given by the second sentence, which provided that section $122(10)$ did not exclude indemnification by any other means. ${ }^{158}$ Professor Folk wrote: "While indemnifying executives for many risks of office is, in the judgment of this Report, to be favored, this objective is not satisfactorily achieved by wording the indemnification statute so broadly that its language authorizes indemnification in obviously inequitable situations. Such, indeed, is a possible construction of present Section 122(10) . . . " 159 Later in his Report, Professor Folk again stressed his position: 'This Report's view is that the 'non-exclusive' provision in Section 122(10) (second sentence) should be eliminated . . . [P] reserving the non-exclusive clause invites misuse of corporate powers for improper indemnification . . . ."160

In light of this it is astounding to see that subdivision ( $f$ ) is a nonexclusivity provision with a vengeance. It provides that section 145 is

154 See text accompanying notes 134-35 supra.

155 See note 121 supra. It is also not stated whether the party seeking indemnification may vote his shares in favor of his own indemnification.

156 Corroon's proposed draft had no such provision (see Corroon Memorandum, supra note 123); nor did Folk's (see FolK REPORT, supra note 69, at 94-96).

157 Folk Interview, supra note 26 . This interpretation makes sense in light of $\$ 143$, which provides that loans may be made to officers and employees without sectrity or interest. See text accompanying note 101 supra.

158 See note 105 and text accompanying notes 106-07 supra.

159 FOLK REPORT, supra note 69, at 76.

160 Id. 92-93. 
not exclusive of any other right that may be provided under any by-law, agreement (presumably, this includes contracts), vote of stockholders or disinterested directors, or otherwise. It then adds that this may apply not only to what the officer or director does in his official capacity, but also to "action in another capacity while holding such office." This would allow the corporation, for example, to cover the cost of an officer or director's automobile accident ${ }^{161}$ or to support his illegitimate children. ${ }^{162}$ Thus, subdivision (f) contains the potential to free officers and directors from any financial liability whatsoever for any wrongdoing.

Why was it retained? Corroon's original draft did not include it, ${ }^{163}$ but after the draft was circulated among various lawyers, objections came back to the committee. These lawyers wanted it retained. ${ }^{104}$ So it was put back for "whatever it was worth"; Corroon feels it is not worth much. ${ }^{165}$ Canby's view on its retention is even more illuminating, both with respect to section 145 and the entire statute. He stated that subdivision $(f)$ was included because the corporation law generally is not meant to limit anyone's imagination. If some lawyer could think of another situation for indemnification-which a court would approve, of course-then why should the draftsmen's limited imagination stop him ? ${ }^{160}$

Finally, subdivision (g) empowers the corporation to purchase and maintain indemnification insurance on behalf of any persons named in subdivisions (a) and (b). This insurance may cover any liability "whether or not the corporation would have the power to indemnify him against such liability under the provisions of this section." In other words, the corporation can do more for management by paying premiums than it can do as a self-insurer. For, if it can get the insurance, ${ }^{167}$ the corporation may now insulate its management from

161 Corroon agreed with this example. Corroon Interview, supra note 35.

162 Professor Folk, who agreed with this example, was not happy with the inclusion of subdivision (f). Folk Interview, supra note 26.

163 See Corroon Memorandum, sispra note 123.

164 Corroon Interview, supra note 35 . Whatever letters were received to this effect could not be located; nor could Corroon remember who had objected.

$165 I d$.

160 Canby Interview, supra note 19.

107 On the subject of indemnification insurance, see, e.g., Bishop, supra note 152, at 1086-1103; Wallace, Facts and Fallacies of Directors' and Officers' Liability, Financiar Executrve, Sept. 1967, at 1; Notè, Public Policy and Directors' Liability Insurance, 67 Colum. L. Rev. 716 (1967); Note, Liability Insurance for Corporate Executives, 80 HARV. L. REv. 648 (1967). The availability and coverage of present policies is a complex subject that will not here be treated in depth, but a few facts may be helpful. Indemnification insurance is not new, having been conceived by Lloyd's after World War II. Within the past six years, however, it has gained prominence; there are now eight American firms writing indemnification insurance: American Home (possibly the leading domestic writer), Liberty Mutual, Kemper, Wassau, Employer Group of Boston, American States Insurance Group (Indianapolis), St. Paul, and Pacific Indemnity. Interview with $R$. Brian Jarman, Assistant Vice President, American Home Assurance Co., in New York City, July 19, 1968. American Home, for one, is treating the insurance very conservatively and it is 
all potential liabilities-including judgments in derivative actions. There are no statutory limits or guidelines on this insurance since Delaware's philosophy is (surprise!) not to regulate. ${ }^{168}$ Professor Folk writes: "In authorizing corporations to take out indemnity insurance, the new law seeks to leave the field untrammeled by restrictions which may turn out to be inappropriate as this new form of liability insurance develops." 169

No explicit provision in either Folk's Report ${ }^{170}$ or in Corroon's draft ${ }^{171}$ authorized insurance; Folk, after receiving a copy of the draft statute, suggested expressly validating the use of insurance, noting that the Model Act people were considering adding such a provision. ${ }^{172}$ Some of the reasons why the drafting committee put it in, and why corporations want it, are well stated in a letter, in the Commission's files, from Ellen Diehlmann, counsel for Johnson \& Higgins, a Wall Street insurance broker writing indemnification insurance: "[The insur-

evidently not easy to get. St. Paul reports that the number of policies they have issued does not exceed 250. Letter from R. S. Almquist, General Liability Underwriter, The St. Paul Insurance Companies, June 14, 1968, on file at the Biddle Law Library, University of Pennsylvania. Mr. Jarman stated that American Home treats it as a defense-cost contract, rather than as a claims contract, and that they have not, to his knowledge, paid out any claims under their policies. Jarman Interview, supra. Mr. Almquist writes that they have had "nine reported incidents involving the cover and the amount to be ultimately paid will be dependent upon the course of present negotiations and development of the case." Letter, supra. As to premium rates: "It is impossible to give you the rates for this coverage as this is dependent upon a number of factors some of which are the number of directors and officers, the size of the business and the type of business." Id. In any event, the SEC does not yet think that indemnification insurance is a problem because the rates are felt to be quite high. Interview with George McHaley, Esq., Division of Corporate Finance, Securities \& Exchange Commission, in Washington, D.C., June 6, 1968.

The reasons for the upsurge in popularity, according to $\mathrm{Mr}$. Jarman, are notoriety of shareholder suits, the fact that people are very "claims" conscious and the fact that insurance companies are trying to make the insurance more acceptable. Acceptability is evidently being brought about in two ways. One is the type of advertisement put out by Johnson \& Higgins, a Wall Street insurance broker, which stresses the possibilities of astronomical liability for officers and directors: a picture of a board of directors, meeting around a table, with a duck at the head, is captioned, "Are you a sitting duck?" Wall Street Journal, Mar. 21, 1968, at 6, cols. 4-6. After all, advertising needs gimmicks and the one being used is "doubt." Jarman Interview, supra. The other way to make the policy more acceptable is to make it clear what the policy covers; the policy is going through numerous changes in wording and $\mathrm{Mr}$. Jarman feels that as more people take it out, the insurance companies will be better able to understand their needs. The American Bar Association is also working to improve the wording; through an Ad Hoc Committee on Indemnification Insurance they are trying to work out a clearer policy by means of "closed door" negotiations with Lloyd's. While this committee has been to London, and will probably go again, they are not certain that anything will be accomplished. Interview with Joseph Hinsey, Esq., Member, Ad Hoc Committee on Indemnification Insurance, in New York City, July 22, 1968. They are not seeking to expand the coverage of the policy. Id. But Stanley Wallace, Vice President of Johnson \& Higgins, believes that the trend is to full indemnity. Interview with Stanley Wallace, in New York City, July 22, 1968.

108 Folk Interview, supra note 26.

169 E. Folk, The New Delaware Corporation Law 14.

170 See FolK Report, supra note 69, at 94-96.

171 See Corroon Memorandum, supra note 123.

172 Letter from Ernest L. Folk, III, to Richard F. Corroon, December 20, 1966, at 1 (on file in offices of Morris, Nichols, Arsht \& Tunnell; Wilmington, Delaware). 
ance] provides a fund which is separate and distinct from corporate assets, from which indemnification can be provided. This avoids completely [sic] the problem inherent in having a corporation give back to a director that which the director is ordered in a judgment to pay to the corporation." 173

Arsht gives a more palatable rationale for allowing the corporation to pay for insurance covering liabilities for which it could not directly indemnify: "This is not, in the Revision Committee's judgment, inconsistent with the policy embodied in the statute. It merely recognizes that to the extent an executive or the corporation may be able to obtain such insurance for the executive's benefit, the corporation may make the premium payments, if it so desires, as a part of his compensation." 174 Sebring, in discussing indemnification insurance, goes even further: "I am perhaps a little unsophisticated on this line, but I feel from my observations that by and large most officer-directors are conscientious men. They are not deterred and they do not need a deterrent through fear of civil liability." 175 But how can Arsht differentiate between money returned by an insurance company and money returned directly by the corporation? Both could be called "a part of his compensation"; both would be a "subversion of fiduciary enforcement." ${ }^{176}$ And how can Sebring reconcile this statement with his earlier one that indemnification of settlement payments "would nullify the derivative action to a large degree?" 177

Perhaps even stranger is the statement of Henry Canby that such insurance "may give rise to questions of public policy." 178 But what is legislation, if it is not a definition of public policy? How can there be a question of public policy, when the statute says that the corporation may insure against liabilities for which it has no power to indemnify directly? Perhaps Canby's statement demonstrates an understanding that the Commission may not have protected the public interest, and that in Delaware, the legislature just does not care. The legislature's stamp of approval is only a procedural technicality; it is up to the courts, if they can, to impose some conception of public policy. If they do not strike down insurance against liability in derivative actions, corporate management will have achieved the result it desired-but could not get-in subdivision (b).

But all the questions raised-proper judicial construction of the statute, mental standards for deserving indemnification, procedure for making such awards-may be almost academic. For there is no pro-

173 Letter to Richard A. Nielsen, January 13,1967 (on file in offices of Morris, Nichols, Arsht \& Tunnell; Wilmington, Delaware).

174 Arsht \& Stapleton, supra note 107 , at 80.

175 Sebring, supra note 108, at 130 (emphasis added).

170 See text accompanying note 137 supra.

177 See text accompanying note 144 sipra.

178 Canby, Delazuare's New Corporation Law, 39 PA. B.A.Q. 380,385 (1968). 
vision that requires that indemnification be disclosed, nor was any ever considered. ${ }^{179}$ Professor Folk stated that he was worried that the "nonexclusive" clause would lead to undiscovered "under the table" indemnification; but he had to admit that "over the table" indemnification was also likely to be undiscovered. ${ }^{180}$ Professor Bishop, after noting that none of the SEC's present rules require such disclosure, writes: "For quite a while to come, my guess is that the case in which a stockholder finds out about and litigates indemnification which he thinks is improper is going to be fairly rare." 181 Perhaps this explains why in the twenty-four years that section 122(10) was in effect, only five suits arose under it. ${ }^{182}$ The only case that Corroon knew of in which the court ordered disclosure of the amount indemnified was the Chrysler litigation. ${ }^{183}$ So not only has management received the very favorable indemnification provision it desired, it has also kept at a minimum the risk that indemnification will ever be challenged in court.

In light of this lack of disclosure, it may be somewhat surprising to turn to section $220(\mathrm{~b})$, which provides that "[a]ny stockholder . . shall, upon written demand under oath stating the purpose thereof, have the right . . . to inspect for any proper purpose the corporation's . . . books and records." Professor Folk's draft of this section would have limited inspection (1) to books and records "of account," (2) by stockholders who either owned five per cent of the outstanding stock or had been stockholders for at least six months. ${ }^{184}$ But Irving Morris, the plaintiff's lawyer on the Commission, opposed the limitations, ${ }^{185}$ and succeeded in having them deleted. The phrase "books and records" should therefore be read rather broadly, and the availability of information would turn on the shareholder's "proper

179 Corroon Interview, supra note 35 . A general disclosure provision was considered and rejected. Id. General motors' by-law on indemnification provides for disclosure to shareholders (see General Motors Notice \& Proxy Statement, sipra note 115, at 40) ; according to Professor Bishop, it is the only one that does. See Bishop, supra note 152 , at $1079-80$.

180 Folk Interview, supra note 27 . In his Report, Folk wrote that preserving the non-exclusive clause invites misuse "to the detriment of the shareholders who will normally remain ignorant." FOLK REPORT, supra note 69, at 93.

181 Bishop, Indemnification of Corporate Directors, Officers and Employees, 20 Bus. LAw. 833, 844 (1965).

182 Teren v. Howard, 322 F.2d 949 (9th Cir. 1963) ; Sorenson v. Overland Corp., 142. F. Supp. 354 (D. Del. 1956), aff'd, 242 F.2d 70 (3d Cir. 1957); Mooney v. WillysOverland Motors, Inc., 106 F. Supp. 253 (D. Del. 1952), aff'd, 204 F.2d 888 (3d Cir. 1953); Essential Enterprises Corp. v. Dorsey Corp., 40 Del. Ch. 343, 182 A.2d 647 (1962) ; Essential Enterprises Corp. v. Automatic Steel Prods., Inc., 39 Del. Ch. 371, 164 A.2d 437 (1960) (according to Judge Seitz, this was the first case construing $\$ 122(10)$ by a Delaware court).

183 Corroon Memorandum, supra note 123. Although the amount indemnified the defendants may have been disclosed in court, the reported case only gives the amounts that the plaintiffs' lawyers received. See Dann v. Chrysler Corp., 42 Del. Ch. 508, 526, 215 A.2d 709, 719 (1965), aff'd, 223 A.2d 384 (Del. 1966).

184 See Folk REPORT, stpra note 69, at 173.

185 See Memorandum from Irving Morris to the Commission, April 19, 1965, at 2 (on file in offices of Morris, Nichols, Arsht \& Tunnell; Wilmington, Delaware). 
purpose." 186 In fact, Morris does not believe that the rest of the Commission really knows what section 220 provides. ${ }^{187}$

What is instructive about section 220 is not so much the fact that Morris seems to have slipped one by the Commission; rather, it is the fact that Morris had no desire to slip anything stronger past. According to Professor Folk, "the point of view of the plaintiff's lawyer was excellently represented by Irving Morris." 188 But Irving Morris operates very much within the system and was not about to ask for radical change. He wrote that the law should be changed only if it would help solidify "Delaware's position as a 'good' State in which to incorporate" or if it would help corporate counsel to act with a substantial degree of certainty. ${ }^{189}$ To provide a broader shareholder right to information, to help lift the veil of secrecy that covers so much of a corporation's activities, ${ }^{190}$ is not favored by Morris, who notes that Delaware law has always provided that the directors run the company; a broad information provision would run counter to its policy. ${ }^{191}$

Two other features concerning shareholders deserve mention, for on the surface they evidence some solicitude for the shareholder who wishes to bring a derivative suit. One is the lack of a securities-forexpenses statute; both Folk ${ }^{192}$ and Morris ${ }^{193}$ agreed that no such statute was necessary. Professor Bishop has written: "It might . . . occur to a cynical mind that this curious anomaly of the Delaware law may not be wholly unconnected with the fact that the prosecution or defense of a derivative suit in a Delaware court requires the retention of Delaware counsel." 194 Mr. Morris agreed with this observation. A securities-for-expenses statute never received any sort of favorable response from the Commission because the lawyers do not want to discourage litigation. Further, such a statute might have been interpreted to allow the plaintiff to solicit other shareholders to join him. What board of directors wants someone writing to their shareholders about alleged wrongdoings? ${ }^{195}$

Another provision of apparent benefit to shareholders is sequestration, which provides that a nonresident director's stock may be seized to compel his appearance; if he fails to appear, the stock may be sold. ${ }^{196}$ In fact, the defendant need not have stock in the corporation involved

186 Folk Interview, supra note 26.

187 Morris Interview, sipra note 22.

188 Folk Letter, supra note 52, at 2.

${ }^{189}$ Memorandum from Irving Morris to the Commission, October 1, 1964, at 2

(on file in offices of Morris, Nichols, Arsht \& Tunnell; Wilmington, Delaware).

190 See note 249 infra and accompanying text.

101 Morris Interview, supra note 22.

102 See Folk Report, sipra note 69, at 103-107.

$193 \mathrm{See}$ Memorandum from Irving Morris to the Commission, supra note 189, at 2. 194 Bishop, New Cure for an Old Ailment: Insurance Against Directors' and Officers' Liability, 22 Bus. Law. 92, 94-95 (1966).

195 Morris Interview, supra note 22.

196 See Del. Code Ann. tit. 10, $\$ 366$ (1953). 
in the suit; in Trans World Airlines, Inc. $v$. Hughes, ${ }^{107}$ the Court of Chancery ordered the seizure of Ernest Breech's Ford stock, despite the fact that Ford had no connection with the litigation. This sounds like strong medicine and there was a spirited fight over retention of the provision.

Irving Morris wrote to Chief Justice Southerland: "I strongly favor the retention of our sequestration procedure as we presently have it. . . Without sequestration the procedural problems might well prove to be insurmountable in bringing to account those who would violate the trust placed in them by stockholders." 198 Professor Folk wrote in his Report that "[r] epealing sequestration will likely weaken remedies for effective enforcement of fiduciary duties, especially if the revisions liberalize aspects of Delaware corporate practice." 190 At the thirty-first meeting of the Commission, "[t] he Secretary of State reported that many complaints from respected law firms outside Delaware have been received by his office regarding the current state of the sequestration law." 200 At the thirty-second meeting, Mr. Jervis, of the Corporation Trust Company, "reported that many of the corporations which his company serves had complained about the Delaware sequestration statute and he stated that, in his opinion, Delaware has lost prospective corporations because of the statute." 201 At the thirtythird meeting, Mr. Jackman, President of the United States Corporation Company, joined Jervis in asserting that corporations were fearful of sequestration. ${ }^{202}$ Could it be that directors and officers would prefer not to be forced to chance liabliity in litigation? Of course not. At the thirty-second meeting, "Mr. Arsht stated that he had discussed the problem with numerous members of the New York Bar and all had said they saw no great objection to the Delaware practice since they felt Delaware was a more favorable forum than any other available." 203

The final vote was five in favor of retaining sequestration, and four in favor of abolishing it (the Chairman, Chief Justice Southerland,

10740 Del. Ch. 523, 185 A.2d 762 (1962).

198 Letter from Irving Morris to Honorable Clarence A. Southerland, April 15, 1966 , at 1 (on file in offices of Morris, Nichols, Arsht \& Tunnell; Wilmington, Delaware).

199 FOLK REPORT, supra note 69 , at 265.

200 Minutes of the Delaware Corporation Law Revision Commission, 31st meeting, March 31, 1966, at 4 (on file in offices of Morris, Nichols, Arsht \& Tunnell; Wilmington, Delaware).

201 Minutes of the Delaware Corporation Law Revision Commission, 32d meeting, April 15, 1966, at 1 (on file in offices of Morris, Nichols, Arsht \& Tunnell; Wilmington, Delaware).

202 See Minutes of the Delaware Corporation Law Revision Commission, 33d meeting, April 25, 1966, at 2-3 (on file in offices of Morris, Nichols, Arsht \& Tunnell; Wilmington, Delaware). Mr. Jackman maintains that he knows of corporations that had decided not to go to Delaware solely because of sequestration, but he would not name names. Jackman Interview, supra note 32.

203 Minutes 4/15/66, stpra note 201, at 2 (emphasis added). 
did not vote). Dukes and Storey, representing the State, Jackman and Jervis, representing the corporation service companies, voted for abolition; the five practicing lawyers voted for retention. ${ }^{204}$ It is easy to understand why the State and the corporation service companies came out as they did - for both, their position would mean more clients and more money. But why did the corporate lawyers join Morris in protecting the shareholders? Because for all of them, retention of sequestration means more money.

It must first be understood that the controversy was not one of a "long-arm" statute versus sequestration. Not even Morris wanted a long-arm statute. ${ }^{205}$ Secretary of State Dukes pointed out that such a statute would be a red flag to corporations saying "don't come here." ${ }^{208}$ A long-arm statute cannot be evaded, but sequestration--that marvellous remedy for "bringing to account those who would violate the trust placed in them by stockholders"-can be defeated by nonownership or concealment of shares. ${ }^{207}$ Nevertheless, it is a fairly effective way to insure that litigation will be centered in Delaware. It might frighten away some corporations, and it may not reach every defendant, but its abolition would mean that litigation in Delaware courts would decrease, causing Delaware's corporate bar to suffer financially. Professor Folk felt that abolition would attract enough corporations to make up for this lost business. ${ }^{208}$ The lawyers on the Commission evidently disagreed; both Morris ${ }^{209}$ and Corroon ${ }^{210}$ freely admitted that they voted for retaining sequestration because it means more business for them.

\section{The Product: Success and Imitation}

We now have some idea of what the product contains; how well is it selling? The New York Times reports: "Delaware began chartering new companies at a record-breaking clip after it revised and liberalized its corporation laws to meet modern needs [sic]. Before the revisions were made in July, 1967, Delaware was signing up new

204 Corroon Interview, supra note 35.

205 Morris Interview, supra note 22.

206 Corroon Interview, supra note 35.

207 See FolK REPORT, stipra note 69, at 269. Concealment can be accomplished by putting shares in street name. Folk Interview, supra note 26 . See DeI. CH. CT. R $4(\mathrm{dd})(1)(\mathrm{b})$.

208 Folk Interview, supra note 26.

209 Morris Interview, supra note 22.

210 Corroon Interview, supra note 35. Corroon had proposed an amendment to $\$ 366$ that would have avoided the "Breech situation" (see text accompanying note 197 sipra), by providing that "the only property of a nonresident defendant which may be seized ... shall be shares of ... the corporation . . . by or for whose benefit the action is brought." (Undated draft; on file in offices of Morris, Nichols, Arsht \& Tunnell; Wilmington, Delaware). Corroon felt that there was an enormous lack of enthusiasm for the proposal. Corroon Interview, supra note 35 . Jackman, however, stated that he would have liked such a compromise. Jackman Interview, supra note 32 . 
corporations at an average of about 300 a month. . . . [It is now] chartering new corporations at a record rate of 800 a month . . . ." 211 It notes that 56,000 corporations are chartered in Delaware, including more than one third of the companies listed on the New York Stock Exchange and almost half of the nation's one hundred largest industrial concerns. ${ }^{212}$ Such corporations as North American Rockwell, International Telephone and Telegraph, Lorrilard ${ }^{213}$ and United States Steel (in anticipation ${ }^{214}$ ) have come over. The article ends: "Mr. Dukes said the franchise tax will bring the state about $\$ 21$-million in the fiscal year ending June 30." 215 In our free enterprise economy, the success of an improved product will force competitors to redesign their own wares. Corporation law is no exception. For example, Tennessee in 1968 adopted an approximation of the $15 \%$ merger provision as well as the provision eliminating appraisal rights where the stock is traded on a national securities exchange. ${ }^{216}$ California ${ }^{217}$ and Georgia ${ }^{218}$ both moved in 1968 to authorize indemnification insurance. Ohio in 1968 changed its indemnification provision, which was a copy of Delaware's section $122(10),{ }^{219}$ to one that is basically the same as section $145 .^{220}$ Virginia's 1968 revision of its indemnification provision omits the

211 N.Y. Times, Jan. 12, 1969, \$1 (News), at 57, col. 1 .

212 Id.

213 See id. cols. 1-2.

214 United States Steel "moved" on January 1, 1966. In its notice to shareholders, the following reasons were given for moving to Delaware:

In 1901 the Corporation was incorporated in the State of New Jersey as the lawis of that State were then deemed to be well adapted for the conduct of its business. In the intervening years, the General Corporation Law of Delaware has developed, affording a flexible and modern basis for corporate action. Because of the fact that some 44,000 corporations (including 42 of the 100 largest industrial corporations ranked according to sales) are incorporated in Delaware, there is a substantial body of case law, decided by a judiciary of corporate specialists, interpreting the Delaware law in the corporate field. In addition, there are state tax advantages in having a corporate domicile in Delaware rather than in New Jersey and it is expected that over a period of years the tax savings may be substantial.

United States Steel Corp., Notice of Special Meeting of Stockholders and Proxy Statement, Nov. 24, 1965, at 5-6 (on file at the Securities \& Exchange Commission, Washington, D.C.). The move from New Jersey cost U.S. Steel about "a couple of hundred thousand dollars," but they expect to save about $\$ 100,000$ per year in taxes. Interview with Richard M. Hays, Esq., United States Steel Corporation, in New York City, July 22, 1968 [hereinafter cited as Hays Interview]. Their Delaware counsel, is, by the way, Morris, Nichols, Arsht \& Tunnell. See note 29 stipra and accompanying text.

215 N.Y. Times, supra note 212, at col. 3.

216 See Tenn. Code Ans. tit. 48, \$\$48-908, -909(b) (3) (Supp. 1968). Their new indemnification provision, on the other hand, followed New York, rather than Delaware. See id. $\$ \$ 48-407$ to -411 .

217 See Cal. Corp. Code $\$ 830($ h) (West 1968).

218 See GA. Code ANn. tit. 22, \$22-202(16) (1968).

219 See Law of June 14, 1955, v. 126 [1955] Laws of Ohio 440-41 (repealed 1967). 220 The main difference is that "not opposed to" is not included. See OHro REv. CODE ANN. tit. 17, §1701, 13(E) (Supp. 1968). 
phrase "no reasonable cause to believe his conduct was unlawful," and its nonexclusivity clause does not apply to "gross negligence" or "wilful misconduct"; otherwise, it is very similar to section $145 .{ }^{221}$ Pennsylvania wasted less time than most; with stunning originality, they had an exact copy of Delaware's section 145 passed by November 30, 1967.222 They did, however, make one addition. Evidently reflecting Henry Canby's fear that insuring against liability in derivative suits might give rise to questions of public policy, ${ }^{223}$ the Pennsylvania legislature added one sentence to subdivision $(\mathrm{g})$ : "Such insurance is declared to be consistent with the public policy of this Commonwealth."

It is New Jersey, however, which seems to have made the most concerted effort to meet the competition. In a preface to their revision, the New Jersey Corporation Law Revision Commission noted that since World War I, the trend has been to Delaware incorporation and that New Jersey had fallen farther behind in "modernizing" their - corporation law.224 They added: "The Commission trusts that this trend will now be reversed, in light of the revision of the New Jersey corporation laws herewith submitted." 225 To make sure that corporations will get the message, the preface advertises- "New Law Enabling, Not Restrictive"-and notes the Commission's belief that New Jersey has pursued the policy of "flexible and permissive" corporation laws "perhaps further than any other state." 226

New Jersey actually began its revision in 1958, when the Corporation Law Revision Commission was established by statute, ${ }^{227}$ but a "Preliminary Draft" was not completed until October, 1967.228 It would appear that the commission was not spurred to activity until New Jersey lost its old customer, United States Steel, to Delaware in $1966{ }^{229}$ After the 1967 draft was prepared, significant changes were made to reflect the Delaware statute. For example, the indemnification provision. In the Commissioners' Comments to the first draft, it was stated that "indemnification may not be available where liability arises under Federal law." 230 This frightening statement is omitted from the

221 See VA. Cone ANn. tit. 13.1, \$13.1-3.1 (Supp. 1968).

222 See PA. Stat. Ann, tit. 15, $\$ 410$ (Supp. 1967).

223 See text accompanying note 178 supra.

224 The situation has come full circle. See text accompanying notes 10 \& 17 supra. 225 N.J. Rev. StaT. §14A, at X (1969).

228 Id. XI.

227 Law of April 16, 1958, v. 1, c. 10, [1958] Laws of New Jersey 30-32.

228 This was not actually the first draft. Interview with Alan Lowenstein, Esq., Chairman, New Jersey Corporation Law Revision Commission, in Newark, N.J., July 18, 1968. There is, however, no reference made by the Commission to a prior complete draft.

229 See note 214 supra and accompanying text.

2302 Commarssioners' Conments to Preimminary Draft of Title 14A 37 (1967) (on file in offices of Lowenstein, Sandler, Brochin \& Kohl; Newark, New Jersey). 
Comment accompanying the new provision, ${ }^{231}$ which includes the phrase "not opposed to the best interests of the corporation." 232 The rest of the indemnification provision, although worded slightly differently than Delaware's, provides the same benefits. ${ }^{233}$ Likewise, the statute authorizes loans to officers, as Delaware does, ${ }^{234}$ makes more explicit than Delaware the range of financial benefits the corporation can bestow on officers and directors, ${ }^{235}$ and adopted, after the Preliminary Draft, the $15 \%$ merger provision ${ }^{236}$ and the elimination of appraisal rights where the security is traded on a national securities exchange. ${ }^{237}$

While this may show that other states are attempting to compete with Delaware, ${ }^{238}$ it is doubtful that the competition can ever catch up. Delaware is selling well for a number of different reasons and it is difficult to single out the one most important to management. Of course, the substantive provisions of the statute are attractive; so, too, is the tax structure, which does not include a corporation income tax on companies not doing business in Delaware. ${ }^{239}$ The court system is also very important. Professor Folk writes that the Court of Chancery, the trial court in corporate matters, has a very high level of competence. It has been shaped by "outstanding" and "unusually competent" judges, many of its decisions are never appealed, and the quality of its "logic and thinking considerably exceeds what is found in most state courts and many federal tribunals." Thus "[c]orporations believe that they are getting a fair shake in Delaware even if a decision is adverse." 240 Arsht notes that corporate counsel consider Delaware to be a more favorable forum than any other available; ${ }^{241}$ Jackman believes that the courts are very favorable to corporations. ${ }^{242}$ Whether or not this is so it is important that people such as the president of a corporation service

231 See Memorandum of July 12, 1968 (on file in offices of Lowenstein, Sandler, Brochin \& Kohl; Newark, New Jersey).

232 See N.J. Rev. STar. $\$ 14 A: 3-5$ (2) (1969). In light of this bit of "legislative history," it is interesting to note the following statement: "The Commission sees no benefit in referring to the Preliminary Draft and Comments in future statutory construction." Id. XVI.

233 See id. \$14A: 3-5.

234 See id. at $\$ 14 \mathrm{~A}: 6-11$; text accompanying note 101 supra.

235 For example, it specifically permits furnishing of education, housing, social and recreational services "and other similar aids and services" to directors, officers, and their families. N.J. Rev. StaT. \$ 14A: 3-1(1) (l) (1969). See text accompanying note 100 supra.

236 See N.J. Rev. Stat. § 14A: 10-3(4) (1969).

237 Specifically including over-the-counter markets. See id. §14A: 11-1.

238 Jackman felt that New Jersey is definitely attempting to compete with Delaware. Jackman Interview, supra note 32.

230 See N.Y. Times, supra note 206, at cols. 2-3; cf. E. Folk, THE RED Book Digest of THE New Delaware CoRporation LaW-1967 iv (1968) (numbers 1 and 2 on list of "advantages of the Delaware law"). United States Steel felt that New Jersey's problems, and therefore its future tax needs, were far greater than Delaware's and this factor influenced them in moving to Delaware. Hays Interview, supra note 214.

240 Folk Letter, supra note 52, at 2-3.

241 See text accompanying note 203 supra.

242 Jackman Interview, supra note 32. 
company believe the courts to be favorable. Another point, mentioned by Folk, ${ }^{243}$ Jackman ${ }^{244}$ and Dukes, ${ }^{245}$ is the large body of precedent that has been built up since 1899-lawyers know what they are getting into. This leads to what Professor Folk calls the "snowball effect": "Many corporations have come into the state. Many problems have been satisfactorily litigated. . . More corporations come in, more decisions are rendered, and the statute is brought up to date to meet contemporary corpus needs. A pro-Delaware sentiment grows and grows. Large corporations begin to switch from other states to Delaware. Other corporations begin to inquire why they are doing this and consider why they should not do the same." ${ }^{246}$ All of these factors get mixed together and create that psychological feeling of a "favorable climate for corporations." This climate is hard to duplicate and it makes Delaware the leading seller in its field.

\section{Conclusion}

This Comment has discussed above how Delaware produced its new corporation law, as well as some features of the finished product. More difficult is an evaluation of the consequences of the process described. Some idea is required of what corporation law should seek to accomplish, for it is possible that Delaware is operating properly and the only ill effect of its actions is an unseemly deviation from democratic theory.

The first question is whether corporation law should attempt anything more than to assure that corporations donate some portion of their wealth to the various states. Does the concept of a corporate charter as a "contract" with the state become meaningless as corporation statutes become increasingly liberal? The answer may be "yes," but even if the charter has become meaningless, the reasons for chartering may remain. Economic units need some amount of regulation, since market forces alone will not insure social good, and the charter is one device that has traditionally been used to provide some of this regulation. The device can be used in many ways; if corporation law no longer provides limits on corporate size, antitrust law can fill the gap. The charter is merely a convenient way to give a "corporation" some form, thereby regulating some of its activities, and we could probably get along without charters, using other types of laws to provide whatever regulation may be necessary.

But so long as charters are being used, and there is a corporation law which goes with them, they will give some form and direction to the organization of the economic unit called a corporation. The present conception is of a three-way ordering between shareholders,

243 See Folk Letter, supra note 52, at 3.

244 Jackman Interview, supra note 32.

245 See N.Y. Times, supra note 212 , at col. 1.

246 Folk Letter, supra note 52, at 3. 
management and the state. ${ }^{247}$ Shareholders have certain property rights in their corporation; they select their managers who are given some degree of decision-making power, and the state provides some regulation to safeguard the public interest.

In this three-way arrangement it is not difficult to see which group has the most power. Shareholders may have the right to vote, and can sue for breaches of fiduciary duty, but they have no easy access to all the relevant information needed to make an informed decision. They may wish to know whether high executives are using expense accounts improperly, but they cannot find out. ${ }^{248}$ Shareholders will not even be able to force their corporation to give a divisional accounting, so as to uncover unprofitable divisions, and hence management errors, which get submerged in a general financial report. ${ }^{249}$ Traditional shareholder rights - to maintain control over growth by acquisition, ${ }^{250}$ to retain proportional ownership, ${ }^{251}$ to receive accrued dividends on preferred stock ${ }^{252}$-are rapidly disappearing. State control in the "public interest" has atrophied to the point where even minimum capitalization is no longer required. Management's power has increased; the indemnification provision shows it to have increased at the expense of the public and shareholder.

It is not strange that management's power is increasing, while the state's and the shareholders' decreases. The strange thing is that the rhetoric lingers on. The three-party ordering underlying corporation law no longer reflects economic realities. Economic concentration is increasing rapidly, particularly with the growth of conglomerates. The power of the vote becomes diluted because ownership is spread over a diffuse group, ${ }^{253}$ which is usually apathetic. ${ }^{254}$ Even if an individual

247 Cf. A. BerLe \& G. MEANS, supra note 125 , at 129-34.

248 Ralph Nader submitted a list of "shareholder" questions to General Motors, one of which requested a detailed listing of expense account items of higher executives. General Motors' response, which "viewed them as labeled-i.e. as 'shareholder' questions," was: "General Motors must respectfully decline to submit such a list. Supervision and auditing of executives' expense accounts is a management responsibility." Hearings, supra note 115 , at 741,748 . It is possible, however, that a shareholder could compel G.M. by suit to open its books on this matter. See DEL. Code ANN. tit. 8, \$220 (Supp. 1968); text accompanying notes 184-87 sipra.

249 See Hearings, sitpra note 121, at 430.

250 See text accompanying notes 93-97 supra.

251 See Del. Cone Ann. tit. 8, §101(b) (3) (Supp. 1968).

252 See id. $\$ 242$ (a) (4).

253 A 1951 study showed that slightly over two thirds of the owners of common stock owned less than 100 shares, approximately $98 \%$ owned less than 200 shares, and that the median shareholder holds considerably less than 100 shares. The $98 \%$ who own less than 200 shares hold $42 \%$ of the outstanding common stock. L. KIMnre, Share OWNERship IN THE UNITEd States 43 (1952). General Motors reported that in $1967,42.7 \%$ of the shareholders owned 25 shares or less, $79 \%$ owned 100 shares or less, $10.3 \%$ owned 101 to 200 shares, and $10.7 \%$ owned 201 shares or more. See Nader, General Motors Corp.: Distribution of Ownership and Ability of Managenent to Gain Overwhelming Proxy Support for Position It Urges, in Hearings, supra note 121 , at 106 .

254 See, e.g.y. J. Livingston, The American Stockholder 26 (1958); Glenn, A Sutdy and $A$ Suggestion, 4 VA. LAW WeEkLy Dicta 124-25 (1953). 
shareholder wishes to take an active interest in the financial affairs of his corporation, he may not be able to understand balance sheets which confuse professional analysts. ${ }^{255}$ The easiest thing for an unhappy shareholder to do is sell his stock and put his investment elsewhere. ${ }^{250}$ Further aiding the divorce of ownership and control are the financial intermediaries who are themselves managers. ${ }^{257}$ These institutional investors, by not using their power, assist in insulating management from control. ${ }^{258}$ Faced with these economic realities, it is no wonder that draftsmen of corporation laws choose to whittle away shareholder rights, rather than attempt to bolster them. ${ }^{259}$

Economic realities pressuring states to give up hope for regulation in the public interest have already been noted. ${ }^{260}$ Another factor aiding state abdication may very well be federal legislation. If the Securities Acts are designed to protect investors, why should the states worry? But the process of federal intervention may accelerate as the states liberalize their corporation laws, or attempt to nullify the effect of federal law in areas such as indemnification of insider trading. The growth of "Federal Corporation Law" is no accident.

Delaware corporation law is not holding back these economic realities, and it may be accelerating them. ${ }^{261}$ Provisions that make mergers easier do not hinder economic concentration; provisions intended to insulate management from financial liability will not reverse the trend toward uncontrolled management. None of this answers the question of what corporation law should do, although it does demonstrate some of the consequences of Delaware's corporation law. Corporate chartering considered as a method of economic regulation could, of course, do many things. The states could reassert themselves. They

255 See Stabler, The Conglomerates-Even Accountants Find Some Financial Reports of Combines Baffing, in Hearings, supra note 121, at 431.

$\mathbf{2 5 6}$ Some have attempted to call a stockholder's shift of investment a "vote" (see, e.g., Glenn, supra note 254, at 125), but it is doubtful that the analogy is apt, since a shareholder rarely sells for the purpose of influencing future policies of his ex-company.

257

It is a fair estimate that over a third of the shares of our largest industrial corporations are owned by financial intermediaries such as insurance companies, banks, trust departments, savings and loan associations, and mutual funds. . . . The individual who buys an insurance policy or is covered by a pension fund, or in other ways contributes to the swelling accumulations of the financial institutions, does not even have the paper rights to a voice in management that corporate shareholders have.

Harbrecht, The Modern Corporation Revisited, 64 CoLum. I. Rev. 1410, 1413-14 (1964).

258 See A. Berle, Power Without Property 55-56 (1959).

250 "So through various statutory changes, . . . the stockholders' position, once a controlling factor in the running of the enterprise, has declined from extreme strength to practical impotence. The legal changes probably have merely recognized the underlying economic fact." A. Berre \& G. Means, The Modern Corporation and PrTVATE Property 141 (1933).

260 See text accompanying notes $82-83$ supra.

261 See A. BERLE, mipra note 258 , at 77. 
have long since realized that the desire for profit does not justify deceiving shareholders with watered stock. Why should the desire for profit justify environmental pollution, unsafe products, unsafe working conditions, or deceiving consumers?

But why bother with corporation law? Such a law could not remedy all these abuses; specific legislation may be preferable. Nevertheless, the structure that a corporation law provides may make reform easier. At least, the structure should not make it more difficult. The three-way ordering conception of corporation law gives direction to corporate structure by establishing decision-making power and checks on that power. ${ }^{262}$ If we wish to solve the problems caused by corporate power, a logical place to start would be inside the corporation. Shareholder rights should be recognized as being of limited value in checking management in today's large corporations, but they should not, therefore, be dispensed with. Perhaps. provision should be made for one director to be nominated by shareholders, or mandatory cumulative voting. But whatever the proposal, we should not expect too much from shareholder control; shareholder participation in the largest corporations will probably continue to be virtually meaningless. ${ }^{263}$ Corporation law will have to find other means to check management, and leave behind the illusory theory of shareholder control.

The most obvious way is for the state to reassert itself in limiting corporate power. Even within corporation law as presently written, a start could be made by changing certain provisions that hinder efforts to control economic power. For example, interested-director transactions could be made void, or at least held to a high standard, thus removing one incentive for interlocking directorates. ${ }^{204}$ The state could hold indemnification to narrowly defined areas. It could require a more adequate supply of information, aiding shareholders and the state in uncovering abuses. For example, detailed reporting of industrial technology and costs relating to environmental pollution might be required. What are oil companies doing to avoid drilling disasters at sea? What resources are automobile manufacturers putting into the development of alternatives to the internal combustion engine? What research are mining companies doing to prevent-or cure-black lung disease? To control inflation, we might require more detailed accounting of costs in key industries. If the government were certain that direct and indirect labor costs of a medium priced car amount to only $\$ 300,205$ it could better evaluate what type of price rise automobile

202 "The law of corporations . . . might well be considered as a potential constitutional law for the new economic state ..." A. BERLE \& G. MEANS, supra note 259 , at 357 .

203 See note 121 supra.

264 See Del. Code ANN. tit. 8, 1144 (Supp. 1968). For a breakdown of the interlocks on General Motors' Board of Directors, see Nader, General Motors Corporation: Outside Directorships, in Hearings, supra note 121, at 546-48.

205 See Testimony of Ralph Nader, Hearings, stura note 121, at 267-68. Nader supported his allegation with a unit-cost analysis for one month's production at one 
manufacturers should be permitted after signing new labor contracts. More explicit information on these types of problems may enable us to decide whether a problem is being adequately dealt with by corporations, or whether other action is necessary.

It should be obvious that the government to do this must be the federal government. The position of the states will not change. There is no reason to think that Delaware will go out of business, or that if it did, no other state would seek to take over the business. There are other reasons for preferring the federal government. The largest corporations are not restricted to any one state, nor are the problems they cause so restricted. If corporation law becomes a means for generating information, the solutions will have to be sought through federal legislation or federal administrative action. One could hardly imagine Delaware subjecting General Motors to the close scrutiny that such information provisions would necessitate. Federal legislation would also provide a single forum to attract, and hear, all interest groups. Democratic theory would appear to call for this approach. The job of writing a national law is not something usually assigned to one small state.

A system of federal chartering and corporation law is not a new idea, ${ }^{266}$ and it will not cure all ills. It may end up by looking almost exactly like Delaware's, but it need not. It could apply to only the largest corporations, dealing with their effects in ways that may not be appropriate for smaller corporations. ${ }^{267}$ It could be used in some of the ways suggested above, providing the logical starting point for intelligent control of corporate power. It could make the American public feel that large corporations are not totally beyond their control. The legal tool is there. It is up to Congress to use it.

automobile assembly plant of the Ford Motor Co. See Hearings, supra, note 121, at 277-330. Senator Nelson termed the data "strong evidence," adding that the $\$ 300$ figure "looks a bit high." Id. 275.

266 For a brief history of proposals for national chartering, see Reuschlein, Federalization-Design for Corporate Reform In a National Economy, 91 U. PA. L. REv. 91, 106-07 (1942).

267 See note 118 supra and accompanying text. 